\title{
A Basin Redox Transect at the Dawn of Animal Life
}

\section{Citation}

Sperling, Erik A., Galen P. Halverson, Andrew H. Knoll, Francis A. Macdonald, and David T. Johnston. 2013. A Basin Redox Transect at the Dawn of Animal Life. Earth and Planetary Science Letters 371-372: 143-155.

\section{Published Version}

doi:10.1016/j.epsl.2013.04.003

\section{Permanent link}

http://nrs.harvard.edu/urn-3:HUL.InstRepos:12334297

\section{Terms of Use}

This article was downloaded from Harvard University's DASH repository, and is made available under the terms and conditions applicable to Open Access Policy Articles, as set forth at http:// nrs.harvard.edu/urn-3:HUL.InstRepos:dash.current.terms-of-use\#OAP

\section{Share Your Story}

The Harvard community has made this article openly available.

Please share how this access benefits you. Submit a story.

Accessibility 
Erik A. Sperling ${ }^{1}$, Galen P. Halverson ${ }^{2}$, Andrew H. Knoll ${ }^{1}$, Francis A. Macdonald ${ }^{1 *}$, and David T. Johnston ${ }^{1 *}$

* Corresponding author:

${ }^{1}$ Department of Earth and Planetary Sciences, Harvard University, Cambridge, MA, USA 02138

${ }^{2}$ Department of Earth and Planetary Sciences/GEOTOP, McGill University, Montreal, Quebec, Canada, H3A 2A7

\section{Dr. David T. Johnston}

Department of Earth and Planetary Sciences

Harvard University

Cambridge, MA 02138 USA

617-496-5024 (v)

617-384-7396 (f)

johnston@eps.harvard.edu

Dr. Francis A. Macdonald

Department of Earth and Planetary Sciences

Harvard University

Cambridge, MA 02138 USA

617-496-2236 (v)

617-384-7396 (f)

fmacdon@fas.harvard.edu

Keywords: Cryogenian; Fifteenmile Group; Canada; oxygen; animals; physiology

Number of words in text: 6496

Number of tables: 0

Number of Figures: 9

Number of Supplemental files: 3 
44 Multiple eukaryotic clades make their first appearance in the fossil record between

$45 \sim 810$ and $715 \mathrm{Ma}$. Molecular clock studies suggest that the origin of animal

46 multicellularity may have been part of this broader eukaryotic radiation. Animals

47 require oxygen to fuel their metabolism, and low oxygen levels have been

48 hypothesized to account for the temporal lag between metazoan origins and the

49 Cambrian radiation of large, ecologically diverse animals. Here, paleoredox

50 conditions were investigated in the Fifteenmile Group, Ogilvie Mountains, Yukon,

51 Canada, which hosts an 811 Ma ash horizon and spans the temporal window that

52 captures the inferred origin and early evolution of animals. Iron-based redox

53 proxies, redox-sensitive trace elements, organic carbon percentages and pyrite

54 sulfur isotopes were analyzed in seven stratigraphic sections along two parallel

55 basin transects. These data suggest that for this basin, oxygenated shelf waters

56 overlay generally anoxic deeper waters. The anoxic water column was dominantly

57 ferruginous, but brief periods of euxinia likely occurred. These oscillations coincide

58 with changes in total organic carbon, suggesting euxinia was primarily driven by

59 increased organic carbon loading. Overall, these data are consistent with proposed

60 quantitative constraints on Proterozoic atmospheric oxygen being greater than 1\%

61 of modern levels, but less than present levels. Comparing these oxygen levels against

62 the likely oxygen requirements of the earliest animals, both theoretical

63 considerations and the ecology of modern oxygen-deficient settings suggest that the

64 inferred oxygen levels in the mixed layer would not have been prohibitive to the

65 presence of sponges, eumetazoans or bilaterians. Thus the evolution of the earliest

66 animals was probably not limited by the low absolute oxygen levels that may have 
67 characterized Neoproterozoic oceans, although these inferred levels would constrain

68 animals to very small sizes and low metabolic rates.

69 


\section{Introduction}

71 A number of eukaryotic groups first appear in the fossil record between the Bitter

72 Springs isotope excursion at $\sim 810 \mathrm{Ma}$ and the Sturtian glaciation at $\sim 715 \mathrm{Ma}$ (Macdonald

73 et al., 2010). This apparent radiation includes the first unequivocal appearances of groups

74 such as the vase-shaped microfossils, interpreted to be related to lobose, and perhaps

75 filose, testate amoebae (Porter and Knoll, 2000; Porter et al., 2003), scale microfossils of

76 uncertain phylogenetic affinity (Cohen et al., 2011; Cohen and Knoll, 2012), and simple

77 multicellular and coenocytic green algae (Butterfield et al., 1994). Interestingly,

78 molecular clock studies suggest that the origin of animal multicellularity may have been

79 part of this broader radiation. Studies utilizing different taxa, genes, calibration points

80 and clock models have converged on an estimated divergence of $\sim 800$ Ma for the last

81 common ancestor of animals (Berney and Pawlowski, 2006; Lartillot et al., 2009;

82 Sperling et al., 2010; Erwin et al., 2011; Parfrey et al., 2011). Similar results in these

83 studies, despite broad methodological differences, suggest this divergence estimate is

84 approximately correct. This age finds further support in the appearance of presumed

85 demosponge-specific biomarkers beneath ca. 635 Ma Marinoan glacial deposits (Love et

86 al., 2009; Kodner et al., 2008); as demosponges represent a derived lineage within

87 animals, the origin of the animal crown group must be even deeper in time. If the

88 molecular clock ages and biomarker data are accurate, however, the lack of metazoan

89 body and trace fossils throughout the Cryogenian and early Ediacaran periods presents a

90 conundrum (Erwin et al., 2011). It has been hypothesized that animal body size and

91 diversity may have been limited by relatively low levels of oxygen in the Proterozoic

92 atmosphere and oceans. In such oceans, it is posited that animals could have been 
93 restricted to small and thin body plans that did not fossilize well, with the explosion of

94 larger and ecologically diverse organisms in the late Ediacaran and Cambrian related in

95 part to increasing $\mathrm{O}_{2}$ levels (Cloud, 1968; Rhoads and Morse, 1971; Runnegar, 1982a;

96 Knoll and Carroll, 1999). Consistent with this hypothesis, different geochemical redox

97 proxies support a directional change towards more oxygenated conditions in the latest

98 Proterozoic (reviewed by Och and Shields-Zhou, 2012; Kah and Bartley, 2011).

99 What remains highly uncertain, however, are the atmospheric and oceanic oxygen

100 concentrations prior to and during earliest animal evolution, specifically during the

101 Cryogenian period (850-635 Ma). Oxygen levels are generally assumed to have been

102 relatively low in Cryogenian oceans (e.g. Kump, 2008), but given the lack of widespread

103 paleoenvironmental documentation, the extent to which early animals were limited by

104 low oxygen levels remains unknown. Specifically, the physiological requirements of

105 small animals with low-energy lifestyles that may have characterized the Cryogenian

106 Period were likely different from the larger, more active and muscular organisms

107 preserved in Cambrian rocks. This difference needs to be considered when comparing

108 physiological requirements against the constraints provided by geochemical proxies.

109 Here, we investigate the environmental context of early animal evolution and

110 compare inferred redox constraints with the likely physiological requirements associated

111 with different grades of organization in early animal evolution. Previous iron speciation

112 and sulfur isotope studies of the pre-Sturtian Chuar Group (Canfield et al., 2008; Nagy et

113 al., 2009; Johnston et al., 2010) provide insight into Cryogenian environments, but are

114 limited to a single section deposited between ca. 770 and $742 \mathrm{Ma}$ (Karlstrom et al.,

115 2000). Here we report geochemical redox proxies through seven sections along two 
116 parallel platform-to-basin transects in the early Cryogenian Fifteenmile Group in the

117 Tatonduk and Coal Creek inliers, Ogilvie Mountains, Yukon, Canada (Figs. 1 and 2). The

118 Fifteenmile Group was deposited in a basin that originated during an episode of

119 continental extension (Macdonald et al., 2012) prior to $811.51 \pm 0.25 \mathrm{Ma}$, the U-Pb

120 zircon date on a tuff in the upper portion of the Reefal Assemblage (green line in Mt.

121 Harper Section, Figs. 3 and 6; Macdonald et al., 2010). Thus the Fifteenmile Group spans

122 a time period that significantly preceded the earliest macroscopic multicellular forms in

123 the Ediacaran Period (Narbonne, 2011) but overlaps with molecular-clock estimates for

124 the divergence of crown-group animals (Erwin et al., 2011, and references above).

125 The paleoredox state of shale samples collected from measured stratigraphic

126 sections was investigated using a multi-proxy approach. Specifically, iron speciation data

127 are integrated with major-element and redox-sensitive trace element abundances, total

128 organic carbon (TOC) percentages, and pyrite sulfur isotope values to obtain an estimate

129 of overall water-column redox profiles. Together, the geochemical data from these

130 stratigraphic sections provide the first early Neoproterozoic basin redox transect and give

131 insight into paleoenvironmental conditions in this basin at the dawn of animal life. These

132 data can then be placed in the context of other information constraining Mesoproterozoic

133 and early Neoproterozoic oxygen levels and compared to the likely physiological

134 requirements of early animals.

135

136 2. Geologic Background

137 Neoproterozoic strata in the northern Canadian Cordillera are exposed in

138 erosional windows ('inliers') separated by Phanerozoic cover (Rainbird et al., 1996; 
139 Thorkelson et al., 2005) (Fig. 1). In the Coal Creek inlier, the focus of this study,

140 geological mapping (Fig. 2) and stratigraphic analysis indicate that Neoproterozoic

141 extension produced a series of NNW-side down normal faults, such that the basin, at least

142 locally, deepened towards the northwest in present-day coordinates (Macdonald et al.,

143 2012). The Fifteenmile Group consists of lagoonal, tidal, and supertidal carbonates of the

144 informal Gibben formation, tidal flat and deltaic deposits of the Chandindu formation,

145 and mixed carbonates and siliciclastics of the Reefal Assemblage, which is characterized

146 by $\mathrm{km}$-scale stromatolitic reefs that transition laterally into shale-dominated, deeper water

147 sub-basins (Macdonald et al., 2012). Shales were sampled from two parallel transects

148 across the basin (Fig. 2), including a shorter transect passing a short distance from a

149 stromatolite reef complex into the shale basin (Fig. 4), and a longer transect stepping

150 further into the basin (Fig. 3). Shales were also investigated from exposures of the Reefal

151 Assemblage $\sim 75 \mathrm{~km}$ to the northwest in the Tatonduk inlier that have yielded distinctive

152 scale microfossils (Cohen et al., 2011; Cohen and Knoll, 2012). As Fifteenmile Group

153 strata in the Tatonduk inlier are represented only by shale interbedded with re-deposited

154 carbonate (and no evidence for shallow-water sedimentation), these exposures are

155 interpreted to have formed in a deeper, more distal environment than correlative sections

156 in the Coal Creek inlier (Macdonald et al., 2012); however, displacement along poorly

157 exposed post-Jurassic faults between the two inliers precludes precise paleogeographic

158 reconstruction.

159

160 3. Materials and Methods 
162 analyzed for major and minor-element concentrations, iron speciation systematics,

163 percent carbonate carbon and organic carbon, and pyrite sulfur isotope composition. Iron

164 sequential extraction followed standard protocols for iron carbonate, iron oxide and

165 magnetite extractions (Poulton and Canfield, 2005), while pyrite iron content was

166 quantified using the chromous chloride extraction method (Canfield et al., 1986). Pyrite

167 sulfur isotopes were determined through combustion via a Costech Elemental Analyzer

168 linked to a Thermo Scientific Delta V in continuous flow mode (measured as $\mathrm{SO}_{-} \mathrm{SO}_{2}$ )

169 using $\mathrm{Ag}_{2} \mathrm{~S}$ from the chromous chloride extraction. Major- and minor-element

170 abundances were determined following a standard acid digestion (hydrofluoric,

171 perchloric, hydrochloric and nitric) and measurement with ICP-AES at SGS Laboratories,

172 Canada. Percent carbonate carbon was quantified by percent loss on acid dissolution.

173 Total organic carbon values were determined on acidified samples by combustion within

174 a Carlo Erba NA 1500 Analyzer attached to a Thermo Scientific Delta V Advantage

175 isotope ratio mass spectrometer. Complete materials and methods and precision estimates

176 for each analysis are contained in Supplementary Information.

\section{$178 \quad$ 4. Results}

179 All geochemical measurements are reported in Supplemental Information Tables

1801 and 2. Iron speciation data are plotted against the sequence stratigraphic framework for

181 the Coal Creek inlier (Macdonald et al., 2012) in Figs. 3 and 4. Full redox proxy data are

182 plotted against stratigraphy for the principal investigated sections including the short

183 transect at Reefer Camp (Fig. 5), the long transect at Mt. Harper (Fig. 6), and the deepest- 
184 water section at Mt. Slipper (Fig. 7). Similar plots for sections with more limited data in

185 the Coal Creek inlier (Mine Camp, East Harper and Mt. Gibben) can be found in

186 Supplemental Figs. 1-3, respectively.

$188 \quad 4.1 \quad$ Multi-proxy estimation of paleo-redox state

189 An estimate of water-column redox state was determined using a multi-proxy

190 approach based on iron speciation chemistry, redox-sensitive trace elements (especially

191 Mo and V) and pyrite sulfur isotope values. In iron speciation chemistry, the highly-

192 reactive pool (FeHR) consists of iron in pyrite $(\mathrm{FeP})$ plus iron that is reactive to sulfide

193 on early diagenetic timescales (iron carbonates such as siderite and ankerite, and iron

194 oxides, including magnetite). The remaining unreactive pool (FeU) consists mainly of

195 iron in sheet silicates; the sum of the two pools is total iron (FeT). Key to the geological

196 application of this proxy is the observation that modern sediments deposited under oxic

197 water columns have a FeHR/FeT $<0.38$, while those deposited beneath anoxic water

198 masses generally have FeHR/FeT > 0.38 [Raiswell and Canfield (1998); see also Farrell,

199 (2011), and Supplementary Information for further discussion]. The proxy can also

200 distinguish the nature of an anoxic water column based on the proportion of highly

201 reactive iron that has been sulfidized, with $\mathrm{FeP} / \mathrm{FeHR}$ ratios $>0.80$ indicating an euxinic

202 water column, and lower ratios pointing towards ferruginous conditions (Anderson and

203 Raiswell, 2004; Poulton and Canfield, 2011).

204 Like all proxies, iron speciation has acknowledged caveats. For instance, dilution

205 by turbidites or rapid sedimentation can result in low FeHR/FeT ratios, imparting a false

206 oxic 'signature' to sediments deposited under an anoxic water column (Raiswell and 
207 Canfield, 1998; Lyons and Severmann, 2006). Near-shore or estuarine sediments can trap

208 large amounts of iron oxides, leading to an anoxic FeHR/FeT signature for sediments

209 deposited under oxic conditions (Poulton and Raiswell, 2002). Weathering can oxidize

$210 \mathrm{Fe}^{2+}$ phases to $\mathrm{Fe}^{3+}$ phases, potentially skewing the interpretation of euxinic versus

211 ferruginous conditions (see below), although the FeHR term should remain constant

212 (Canfield et al., 2008). Consistency between independent proxies is the best test of an

213 inference, and consequently we integrated the iron speciation chemistry with other redox

214 proxies and sedimentological constraints. Redox-sensitive trace elements such as

215 vanadium and molybdenum are soluble under oxic conditions but are less soluble under

216 reducing conditions, and are scavenged by organic and inorganic particles or complex

217 with sulfide, leading to enrichments compared to average shale values (Tribovillard et al.,

218 2006). Pyrite sulfur isotope values can further inform paleoenvironmental reconstruction,

219 because sulfate reduction within a water-column where sulfate is not limiting allows

220 expression of the biological preference for lighter ${ }^{32} \mathrm{~S}$, and consequently depleted isotopic

221 compositions in the resulting pyrite with respect to seawater sulfate. Sulfate reduction

222 within sediments, on the other hand, where sulfate availability is often diffusion limited,

223 results in Rayleigh distillation, leading to pyrite values that approach seawater sulfate

224 (Johnston and Fischer, 2012).

225 In our multi-proxy framework, samples were considered likely to have been

226 deposited under an oxic water column when they showed FeHR/FeT $<0.38$ (Raiswell

227 and Canfield, 1998), no enrichment in Mo and V with respect to average shales (Gromet

228 et al., 1984), and relatively enriched $\delta{ }^{34} \mathrm{~S}$ pyrite sulfur isotope values (or not enough

229 sulfide present in the rock for measurement). Samples were considered to have been 
230 deposited under an anoxic, ferruginous water column when they showed FeHR/FeT >

2310.38 , little to no Mo enrichment but often with $\mathrm{V}$ enrichment, and relatively enriched $\delta^{34} \mathrm{~S}$

232 pyrite sulfur isotope values. Finally, samples were considered to have been likely

233 deposited under an anoxic, euxinic water column when they showed FeHR/FeT $>0.38$,

234 relatively high $\mathrm{FeP} / \mathrm{FeHR}$ ratios, Mo and $\mathrm{V}$ enrichments, and depleted $\delta^{34} \mathrm{~S}$ pyrite sulfur

235 isotope values.

236 Euxinic water columns are usually distinguished by FeP/FeHR $>0.80$ or 0.70

237 (Poulton and Canfield, 2011), a ratio which few of these samples surpasses. Samples

238 interpreted here as euxinic, though, clearly have much higher FeP/FeHR ratios than

239 samples interpreted as ferruginous (see Figs. 6 and 7), and essentially no iron carbonate

240 or magnetite. Further, these shales have very depleted $\delta{ }^{34}$ S pyrite sulfur isotopes (to -34

$241 \%$ ) and high molybdenum abundances relative to other Neoproterozoic samples (Scott et

242 al., 2008). Two likely possibilities exist to explain these patterns: 1) these shales were

243 deposited beneath an euxinic water column, with subsequent oxidation of pyrite to iron

244 oxides, or (2) the shales were deposited beneath a ferruginous water column, with the

245 zone of free sulfide accumulation essentially at the sediment-water interface.

246 Petrographic examination of selected shales did not show widespread evidence for

247 oxidation of pyrite, although because the samples are from outcrop and surely have

248 suffered some alteration, it is possible that micron-scale pyrite grains beneath the limits

249 of routine petrographic detection have been wholly or partially oxidized. In the second

250 possibility, full access to seawater sulfate and molybdenum pools could explain the

251 isotopic and abundance patterns for these two elements, while the shorter time interval

252 exposed to high sulfide levels compared to a fully euxinic water column would result in 
253 less sulfidization of highly-reactive iron phases. Recognizing that the development of

254 truly euxinic conditions is ambiguous and these data may represent sulfide production at

255 the sediment-water interface, inferences of euxinia in Figs. 5-7 should be treated with

256 caution.

\subsection{Sedimentary Geochemistry of the Fifteenmile Group}

\subsubsection{Reefer Camp transect, Coal Creek inlier}

Near Reefer Camp, samples from the shallow-water Chandindu formation show

261 the hallmarks of deposition under an oxic water column (Fig. 5A). Within the

262 stromatolite reef core of the Reefal Assemblage, thin black shales show high FeHR/FeT,

263 but because they show no redox-sensitive trace element enrichment, and the FeHR signal

264 is entirely dominated by iron oxides, this may represent nearshore trapping of oxides, as

265 occurs in modern settings (Poulton and Raiswell, 2002) rather than a true ocean redox

266 signal. Samples above the flooding surface atop the stromatolite reef tract have iron

267 speciation values persistently above 0.38 , moderate amounts of iron carbonate, no Mo

268 enrichment and enriched pyrite sulfur isotope values, pointing to deposition under

269 ferruginous conditions. Samples from the upper part of the Reefal Assemblage signal an

270 apparent return to oxic deposition. In Fig. 5B (See Fig. 4 for the stratigraphic relationship

271 of these sections), the Chandindu formation samples again show evidence for oxic

272 deposition. Continuing upsection into shale of the Reefal Assemblage, all available

273 evidence points to deposition under a generally oxic water column. 
277 evidence for oxic deposition (Fig. 6). The Mt. Harper transect steps much farther

278 westward into the Reefal Assemblage shale basin than the short transect at Reefer Camp,

279 and records a thick package of black shale and foreslope carbonate that fill

280 accommodation space associated with tectonic extension (Macdonald et al., 2012). In

281 section GO134, the stratigraphically lowest exposed shales of the Reefal Assemblage,

282 there is evidence for euxinic deposition. Many of these samples do not show FeHR/FeT >

2830.38 , but as this succession contains many siltstone turbidites and redeposited carbonates

284 and was likely deposited rapidly during active extension (Macdonald et al., 2012), it is

285 possible that the highly-reactive iron was diluted by high sedimentation rates. Thus a

286 threshold for anoxia of 0.22 may be more appropriate (Raiswell and Canfield, 1998; see

287 also discussion in Supplementary Information). These samples show relatively high

288 FeP/FeHR, high Mo ( 10-32 ppm; high for Neoproterozoic shales—Scott et al., 2008),

289 and depleted pyrite sulfur isotope values, indicating sulfide production very near to the

290 sediment-water interface, if not in the water column (see above). The upper half of

291 section GO134 shows lower Mo and less depleted pyrite sulfur isotope values, potentially

292 suggesting ferruginous or even oxic conditions. Samples at the base of section S1103

293 have FeHR/FeT < 0.38, no redox-sensitive trace element enrichments, and no pyrite,

294 possibly recording deposition under oxic conditions. This is followed by a second pulse

295 of euxinic deposition, showing similar characteristics to the samples in GO134, with

296 elevated $\mathrm{FeP} / \mathrm{FeHR}$, high Mo abundances, and depleted pyrite sulfur isotope values.

297 There is little evidence for euxinia above this level, with ferruginous conditions dominant

298 in the upper Reefal Assemblage. In contrast to samples from the lower Reefal 
299 Assemblage at Mt. Harper, where the FeHR pool is almost entirely in pyrite and iron

300 oxides, samples from the upper Reefal Assemblage contain moderate quantities of iron

301 carbonate. In combination with low Mo, and enriched and variable pyrite sulfur isotope

302 values, this suggests that the upper half of the Reefal Assemblage accumulated under an

303 anoxic, ferruginous water column. Brief and fluctuating water column oxygenation may

304 have occurred, as evidenced by stratigraphically-variable iron speciation signatures.

\subsubsection{Mt. Slipper, Tatonduk inlier}

307 Iron speciation values from the Reefal Assemblage in the Tatonduk inlier (Figure

308 7), which represent the deepest-water setting studied (Macdonald et al., 2012), generally

309 show FeHR/FeT $>0.38$, indicating persistent deposition under an anoxic water column.

310 Samples from the base of the section have relatively high FeP/FeHR, high Mo and

311 depleted pyrite sulfur isotope values, pointing to euxinic deposition (or at least

312 fluctuating euxinia). At $\sim 90 \mathrm{~m}$, these proxy values decrease, indicating a transition to

313 ferruginous conditions. A possible return to euxinia is seen at the top of the section, from

314 strata that have yielded scale microfossils (Cohen et al., 2011).

\subsubsection{Sediment total iron contents}

317 The total iron to aluminum ratio is another informative redox proxy, because

318 sedimentary iron is authigenically enriched under anoxic water columns (Lyons and

319 Severmann, 2006). An interesting feature of shale samples from the Fifteenmile Group is

320 that even samples considered to have been deposited under anoxic conditions have $\mathrm{Fe} / \mathrm{Al}$

321 ratios lower than average shale (Gromet et al., 1984). Given the general concordance in 
322 these samples of $\mathrm{FeHR} / \mathrm{FeT}$, redox-sensitive trace element abundances and pyrite sulfur

323 isotope data, the inconsistency with Fe/Al likely indicates an intrinsic bias to either total

324 iron or total aluminum in the Reefal Assemblage, rather than this representing oxic

325 deposition. Total $\mathrm{Al}$ abundances in all shales investigated (average $=7.03 \mathrm{wt} \%$ ) are

326 slightly depressed relative to the North American Shale Composite (NASC; Gromet et

327 al., 1984; $8.94 \mathrm{wt} \%$ ). In contrast, total $\mathrm{Fe}$ (average $=2.43 \mathrm{wt} \%$ ) is significantly reduced

328 relative to NASC (4.43 wt \%), especially considering that basinal samples interpreted as

329 anoxic should be enriched in iron. Some Reefal Assemblage shales are exceptionally low

330 in total iron ( $<1$ weight percent), and have very high FeHR/FeT ratios indicating a near-

331 absence of detrital iron-silicates. Dilution by carbonate may explain some of the low iron

332 contents, as some samples are slightly calcareous (to $\sim 30-40 \%$, average $9.45 \% \pm 9.50$ ),

333 Supplementary Table 1) but low iron contents persist in shale samples that have

334 essentially no carbonate (e.g. GO134 and S1103 sections). Open-system diagenesis could

335 have potentially affected these rocks, although even the marls would have had very low

336 permeability. Further, the main effect of diagenesis in carbonates is to add iron (Brand

337 and Veizer, 1980), which is unlikely given the low overall amounts of acetate-extractable

338 iron (average 0.13 weight percent) and the lack of a relationship between percent

339 carbonate and acetate-extractable iron $\left(R^{2}=0.062\right)$. Another possibility is that the

340 provenance was extremely weathered, iron-free material. However, Chemical Index of

341 Alteration (CIA; Nesbitt and Young, 1982) values average $\sim 70$ throughout the dataset,

342 indicating a fairly unweathered provenance. A few values in the 75-85 range suggest a

343 weathered source for those samples, but overall there is no obvious correlation between

344 CIA and total iron. Thus, while several factors may explain some low iron values, none 
345 can explain all low values. We note that some other Neoproterozoic sections show

346 anomalously low FeT/Al (e.g. Sahoo et al., 2012); further study is needed to determine if

347 these are local, basin-level effects or an as-yet-unexplained aspect of the Neoproterozoic

348 iron cycle.

\subsubsection{Redox proxy data and sediment organic carbon contents}

351 Sediment TOC results vary consistently compared to multi-proxy inferences of

352 redox state (Fig. 8). Sediments likely deposited under an oxic water column have low

353 organic carbon abundances (average $=0.31 \% \pm 0.49$ weight percent; median $=0.19 \%$ ),

354 whereas those inferred to have been deposited beneath a ferruginous water column have

355 higher sediment TOC values (average $=0.66 \% \pm 1.37$; median $=0.28 \%$ ). And sediments

356 likely deposited beneath euxinic conditions show much greater TOC (average $=2.87 \% \pm$

$3571.49 ;$ median $=2.63$. Thus, these data are consistent with the hypothesis that the

358 development of euxinic conditions in Neoproterozoic basins is primarily driven by the

359 degree of organic carbon loading and the exhaustion of more energetically-favorable

360 electron acceptors than sulfate (e.g. Fe $\left.{ }^{3+}\right)($ Johnston et al., 2010).

\subsubsection{Redox proxy data and water depth}

363

Redox proxy data show a consistent pattern with respect to sedimentological

364 structures that indicate relative water depth. In particular, all occurrences of hummocky

365 cross-stratified sandstones encased within shale, which indicate deposition above storm

366 wave base, show evidence for oxic deposition (Fig. 3-7). In other words, the surface

367 mixed layer in the basin appears to be oxygenated, at least during storms. While the depth 
368 of storm wave base varies among basins (Peters and Loss, 2012), these data indicate that

369 in this basin, the water column in direct contact with the atmosphere remained oxic.

370 Oxygenated conditions may extend slightly deeper, as some sediments likely deposited

371 below storm wave base (such as shales basinward of the stromatolite reef at Reefer

372 Camp, Fig. 5B) still indicate oxic conditions. A few brief intervals of oxygenated

373 conditions, or fluctuating anoxia, persist deeper into the Coal Creek inlier shale basin as

374 recorded in the Mt. Harper (Fig. 6) and Mine Camp (Supplementary Fig. 1) sections, but

375 the majority of these deeper-water sediments record anoxic conditions. The deepest-water

376 section at Mt. Slipper in the Tatonduk inlier (Fig. 7), which shows no evidence for wave

377 activity, is persistently anoxic. Thus, there is a clear redox structure to the basin, with an

378 oxygenated surface layer where the sediments are in contact with the atmosphere (storm

379 wave base), and anoxic conditions below this depth.

380

$381 \quad$ 5. Discussion

$382 \quad 5.1 \quad$ Fifteenmile Group redox structure in a global context

383 Quantitative constraints on Proterozoic oxygen levels are notoriously difficult to

384 obtain (Kump, 2008). $\mathrm{O}_{2}$ levels must have been above $0.001 \%$ present atmospheric levels

385 (PAL), the limit imposed by the disappearance of mass-independent fractionation of

386 sulfur isotopes at $2.45 \mathrm{Ga}$ (Farquhar et al., 2000; Pavlov and Kasting, 2002). Two other

387 constraints have been proposed for mid-Proterozoic $\mathrm{O}_{2}$ (Kump, 2008). First, anoxic deep

388 oceans likely require atmospheric $\mathrm{O}_{2}$ to be less than 40\% PAL (Canfield, 2005). Second,

389 it has been proposed that iron is only retained in lithified soil horizons, and it has been

390 since the Paleoproterozoic, when $\mathrm{O}_{2}$ is greater than 1\% PAL (Holland and Beukes, 1990). 
391 These limits on Proterozoic $\mathrm{O}_{2}$ have caveats, and it has even been hypothesized that

392 levels may not have been dramatically different from the Phanerozoic (Butterfield, 2009).

393 Nonetheless, it is notable that the basin redox transect of the Fifteenmile Group is

394 consistent with proposed quantitative limits (Kump, 2008). Indeed, the basin redox

395 structure of the Fifteenmile Group is similar in many ways to that of the Mesoproterozoic

396 Roper Group in Australia (Shen et al., 2003), with an oxygenated shelf overlying anoxic

397 basinal waters. Although there are local drivers for anoxia (Tyson and Pearson, 1991), the

398 available basin redox transects point to extensive subsurface anoxia in the Proterozoic

399 oceans, sustained over hundreds of meters of stratigraphic section. This clearly differs

400 from Phanerozoic ocean anoxic events (Campbell and Squire, 2010), indicating a

401 different driver and implying lower atmospheric $\mathrm{O}_{2}$ than the modern. Placing minimum

402 constraints on global atmospheric $\mathrm{pO}_{2}$ levels from local iron speciation data is difficult,

403 but shallow-water facies in the Fifteenmile Group record oxic deposition, as do samples

404 from the shale basin just off the reef margin at Reefer Camp (Fig. 5), and some samples

405 from deeper in the shale basin at Mt. Harper (Fig. 6) and Mine Camp (Supplementary

406 Fig. 1), implying enough atmospheric oxygen to counteract strong benthic reductant

407 fluxes in a basin otherwise prone to euxinia (cf. Kump et al., 2005).

408 In sum, although there is clear need to study more basins, and develop new global

409 redox proxies and models, the basin redox transect of the Fifteenmile Group is consistent

410 with proposed constraints on Proterozoic oxygen levels as being $<40 \%$ and $>1 \%$ PAL

411 (Kump, 2008). We apply these bounds for comparison with the physiological

412 requirements of early animals.

413 


\section{$414 \quad 5.2 \quad$ Physiological requirements of early animals}

415 The consistency of previously proposed constraints on atmospheric oxygen with

416 the basin redox transect of the Fifteenmile Group prompts the question of whether such

417 oxygen levels would have prohibited the evolution of animal, eumetazoan or bilaterian

418 body plans. A common assumption in attempts to link late Precambrian oxygenation and

419 biospheric evolution is that animals have high respiratory demands. While metazoans do

420 have a clear and definite requirement for oxygen, they are not a monolithic group, and the

421 oxygen requirements for any given organism varies widely based on size, metabolism,

422 and the presence or absence of a circulatory system (Vaquer-Sunyer and Duarte, 2008).

423 Hypotheses relating geochemical change to early animal evolution must therefore

424 compare inferred changes against the explicit body plans, ecological strategies and

425 taxonomic groups presumed to be affected. Determining the physiological requirements

426 of ancient organisms has obvious uncertainty, but can be accomplished through analogy

427 with living representatives (Knoll et al., 2007), and thus it is possible to make general

428 statements about the likely oxygen requirements of Precambrian animals.

\section{$430 \quad$ 5.2.1 Diploblastic metazoans}

431 Whether sponges are monophyletic (Philippe et al., 2009) or paraphyletic

432 (Sperling et al., 2009), they are certainly the sister group or grade of all other animals

433 (Philippe et al., 2011). Moving up the metazoan phylogenetic tree, the exact relationships

434 of cnidarians, ctenophores and placozoans to bilaterians are unclear, but all are likely

435 more closely related to bilaterians than they are to sponges (Philippe et al., 2011).

436 Importantly, all these animals (diploblasts) are characterized by only two epithelial cell 
437 layers, with the space between layers filled largely with metabolically-inert material (e.g.

438 mesohyl in sponges, mesoglea in cnidarians). From a respiratory point of view, then,

439 essentially every cell in a diploblastic metazoan is in direct contact with seawater

440 (Ruppert et al., 2004). Thus, the theoretical oxygen limit for diploblastic animals will not

441 differ from that of a single-celled eukaryote, barring two minor differences. First, for

442 unicellular eukaryotes, diffusion of oxygen into the cell can occur across the entirety of

443 its surface, whereas diffusion into a sheet of cells cannot occur at cell-cell contacts.

444 Second, animals have a collagenous extracellular matrix, and molecular oxygen is

445 required for the formation of hydroxyproline in collagen (Fujimoto and Tamiya, 1962;

446 Prockop et al., 1962). Using the $\mathrm{Km}$ for the proline hydroxylase system of chick embryos,

447 Towe (1970) suggested oxygen levels of $~ 3 \%$ PAL would be required for collagen

448 synthesis. However, Rhoads and Morse (1971) cogently noted that collagen-rich

449 invertebrates are found at oxygen levels beneath this value (see also discussion below on

450 modern oxygen minimum zones), suggesting that the oxygenase requirements of a

451 terrestrial vertebrate cannot be applied to marine invertebrates. Further, collagen is now

452 known to exist in fungi (Celerin et al., 1996; Wang and St. Leger, 2006) and

453 choanoflagellates (King et al., 2008--although the homology of both to metazoan

454 collagens remains uncertain), which suggests collagen may have been present in the last

455 common ancestor of opisthokonts. If so, any oxygen requirement for collagen synthesis

456 was met far earlier than the origin of animals.

457 In the fossil record, clear eukaryotic organisms are found at $\sim 1800 \mathrm{Ma}$, and

458 several lineages of multicellular eukaryotes, which would also have been subject to the

459 same constraint as early animals of limited diffusion at cell-cell contacts, are found in 
460 Mesoproterozoic rocks (Runnegar, 1991; Knoll et al., 2006). The presence of these

461 organisms long before the Cryogenian implies that any physiological oxygen threshold

462 for the body plans that characterized the earliest (diploblastic) period of early animal

463 evolution must have been surpassed far prior to the origin of animals themselves.

\section{$465 \quad 5.2 .2$ Bilaterian metazoans- theoretical lower oxygen limits}

466 In contrast to diploblasts, which have sheets of cells separated by inert material, 467 bilaterian (triploblastic) organisms have metabolically-active cells in three-dimensions 468 (Knoll, 2011). Body size (and the ability of the organism to exist at a given oxygen 469 concentration) is consequently limited by the ability to maintain functional internal 470 oxygen levels, either through pure diffusion or through a blood vascular system (BVS). 471 The implications of this constraint under hypothetical Precambrian oxygen levels have 472 been extensively discussed (e.g. Raff and Raff, 1970; Runnegar, 1982a,b; 1991; Catling 473 et al., 2005; Payne et al., 2010). Using a theoretical framework for the diffusion of 474 oxygen into an idealized animal (Alexander, 1971), these studies have demonstrated that 475 low oxygen levels will restrict bilaterians to small, thin body plans. What has not been 476 asked in these theoretical calculations is what oxygen levels will prohibit the existence of 477 bilaterian body plans.

478 Superficially, this question would seem to hinge on the nature of the last common 479 ancestor of bilaterians (consider Carroll et al., 2001, versus Erwin and Davidson, 2002), 480 specifically whether this ancestor was a complex, coelomate organism with a heart and 481 BVS, or a much simpler organism that transported oxygen through pure diffusion.

482 However, as noted by Budd and Jensen (2000), due to structural size requirements, 
483 notably the physical space required to fit a functional BVS, this transport system is not

484 present in modern organisms less than $\sim 3 \mathrm{~mm}$ in size. Following the framework of

485 Alexander (1971; see Supplementary Information for details), we estimate that the most

486 likely minimal oxygen requirement for a 3 mm-long x $67 \mu \mathrm{m}$-wide worm with a

487 circulatory system, such as an annelid, is $\sim 0.14 \%$ PAL (Fig. 9). The most likely minimal

488 oxygen requirements for a $600 \times 25 \mu \mathrm{m}$ diameter worm limited by pure diffusion, such as

489 a nematode, is $\sim 0.36 \%$ PAL (Fig. 9) — note that these values are with respect to ambient

490 dissolved oxygen concentrations and do not consider temperature or salinity effects on

491 the dissolution of oxygen in water. The estimated oxygen requirements for these two

492 hypothetical ancestors differ slightly, but their broad similarity and the overlap in

493 sensitivity analyses (Fig. 9) suggests that pure diffusion and a BVS likely represent

494 optimal designs below and above this size threshold.

495 Although there are uncertainties in the optimal values for the parameters in the

496 equations governing oxygen requirements (see Supplementary Information), three facts

497 suggest the values described above represent conservative estimates for the minimum

498 oxygen concentrations necessary to sustain bilaterians. First, for the bilaterian limited by

499 pure diffusion, a sensitivity analysis (Fig. 9 and Supplementary Table 7) demonstrates

500 that one of the most important terms at very low oxygen levels is the minimum cellular

501 oxygen concentration. This will be a small, but non-zero, number (Raff and Raff, 1970).

502 Raff and Raff (1970) used a value of $1 / 10^{\text {th }}$ the shared $K m$ of yeast and mammalian

503 cytochrome oxidase. Here, rather than adopting an arbitrary but likely more accurate

504 fractional value, we use the shared yeast-mammal $K m$ (Chance, 1957) as our 'most

505 likely' value for this parameter (note that investigated invertebrate cytochrome oxidases 
506 have a similar value (e.g. Gnaiger et al., 2000)). This ensures that the most important

507 parameter in the model is an over-estimate. Second, for the hypothetical ancestor with a

508 circulatory system, we assumed the organism did not have respiratory pigments.

509 Although the homology of metazoan respiratory pigments is unclear (Terwilliger, 1998),

510 their presence in this hypothetical last common bilaterian ancestor would greatly increase

511 diffusion rates. Thus, our assumption that respiratory pigments were absent again results

512 in a conservative estimate. Finally, and most importantly, these theoretical calculations

513 assume a perfectly tubular organism (Alexander, 1971). Such an organism does not exist,

514 as real animals have body wall rugosities, gills, and other structures that dramatically

515 increase diffusive surface area with respect to volume; even the gut is a gas-exchange

516 organ. Consequently, these 'most likely' values and the sensitivity analyses are not

517 intended to yield a precise number. Rather, these models provide an indication of the

518 lower bound of oxygen levels necessary to preclude the bilaterian body plan from

519 Proterozoic oceans. No matter the complexity of the last common ancestor of bilaterians,

520 theoretical modeling suggests the bilaterian body plan was unlikely to have been

521 prohibited unless $\mathrm{O}_{2}$ levels were $<0.4 \%$ PAL.

522

\section{$523 \quad 5.2 .3 \quad$ Bilaterian metazoans- empirical lower oxygen limits}

524 These theoretical calculations can be tested with empirical observations of the 525 oxygen limits of bilaterians in modern oxygen-minimum zones (OMZs). Unlike the biota

526 on shelves or in regions of anthropogenic eutrophication that show deleterious oxygen

527 responses at relatively minor oxygen depletions (Diaz and Rosenburg, 1995; Levin et al.,

528 2009), OMZs have experienced geologically long-lasting dysoxic- to anoxic conditions, 
529 allowing the fauna to adapt to these levels and providing an excellent analogue for

530 Precambrian oceans with persistently low oxygen levels. It should be noted that

531 organisms in modern OMZs have likely secondarily adapted to these environments rather

532 than originating in them. Thus, the type of adaptations allowing organisms to inhabit

533 these environment must be considered. For example, organisms with extreme metabolic

534 adaptations, such as amitochondriate loriciferans living in an euxinic Mediterranean basin

535 (Danovaro et al., 2010), cannot inform us about Precambrian animal evolution, as the

536 transformation of the mitochondria into a hydrogenosome was certainly not a primitive

537 feature. Most of the adaptations allowing bilaterians to inhabit modern low-oxygen

538 environments, though, appear to lie in their very small, thin body plans (with high

539 surface-area to volume ratios for increased diffusion) and enlarged respiratory organs

540 (Levin, 2003; Gooday et al., 2010; Jeffreys et al., 2012; Lamont and Gage, 2000; Neira et

541 al., 2001) — that is, with morphological adaptations that would have been possible, and

542 perhaps likely, in early bilaterians. Consequently these animals can provide a useful

543 analogue for Precambrian animal life in low-oxygen conditions.

544 In using OMZs as Precambrian analogues, it has long been recognized that the

545 faunas are characterized by such small, thin, body plans (Rhoads and Morse, 1971). What

546 has emerged in the four decades of oceanographic research since Rhoads and Morse's

547 seminal paper is just how little oxygen is actually required by bilaterian animals. It is now

548 clear that non-chemosymbiotic benthic macrofaunal (retained on $0.3 \mathrm{~mm}$ sieves)

549 bilaterians can and do live in Rhoads and Morse's 'azoic' zone of $<0.10 \mathrm{~mL} / \mathrm{L}$ oxygen ${ }^{1}$

\footnotetext{
${ }^{1}$ A difficulty in interdisciplinary research on the biological effects of differing oxygen levels is the use of different units by different research communities (Hofmann et al.,
} 
550 (Levin, 2003; Gooday et al., 2010; Levin et al., 2000; Palma et al., 2005; Zettler et al.,

551 2009; Levin et al., 1991; Levin et al., 2002; Ingole et al., 2010), often with densities of

552 hundreds to thousands of animals per square meter. Bilaterian faunas can even be found

553 as low as $0.02 \mathrm{ml} / \mathrm{L} \mathrm{O}_{2}$, equivalent to $\sim 0.3 \%$ of modern surface ocean levels (assuming a

554 normal surface ocean concentration of $\sim 6 \mathrm{~mL} / \mathrm{L}$ ) in the OMZ off Chile (Palma et al.,

555 2005), Peru (Levin et al., 2002) and the Bay of Bengal (R. Akkur, pers. comm.). The

556 exact oxygen concentrations actually required to exclude bilaterians are likely even

557 lower, these oxygen measurements are determined from $\mathrm{O}_{2}$ sensors or seawater samples

558 from CTD casts collected several meters ( $\sim 5 \mathrm{~m})$ above the seafloor. The oxygen levels at

559 which bilaterians are recorded (namely $0.02 \mathrm{~mL} / \mathrm{L}$ ) approach the detection limit of the

560 Winkler titration technique (Paulmier et al., 2006), and CTD cast values generally over-

561 estimate in-situ benthic conditions (Breur et al., 2009). Thus, both theoretical calculations

562 and empirical observations in modern OMZs suggest the presence of bilaterians would

563 not have been limited unless atmospheric $\mathrm{O}_{2}$ was considerably less than $1 \% \mathrm{PAL}$, and

564 likely less than $0.4 \%$ PAL.

565

566 7. Conclusions

567 Geochemical transects of the $\sim 800$ Ma Fifteenmile Group in the Ogilvie

568 Mountains document shallow-water facies characterized by low FeHR/FeT, a lack of

569 enrichment in redox-sensitive trace elements, and relatively heavy and variable pyrite

570 sulfur isotope values. Deeper-water facies (those deposited below storm wave base) are

571 characterized by $\mathrm{FeHR} / \mathrm{FeT}>0.38$, enrichment in redox-sensitive trace elements, and

2011). For consistency here we report oxygen levels as in the benthic ecology literature $(\mathrm{mL} / \mathrm{L})$. For reference $0.01 \mathrm{~mL} / \mathrm{L} \approx 0.44 u \mathrm{~mol} / \mathrm{kg} \approx 0.014 \mathrm{mg} / \mathrm{L} \approx 0.4 \mathrm{matm}$. 
572 more depleted pyrite sulfur isotope values. Overall, this points towards an oxygenated

573 surface layer, down to storm wave base, overlying a generally anoxic deep basin.

574 Fluctuations between euxinic and ferruginous conditions sub-storm wave base appear to

575 have been controlled by variations in organic carbon loading. As proxies like iron

576 speciation and redox-sensitive trace elements provide evidence of local environments,

577 more geochemical studies from other basins are necessary to begin building the global

578 picture of redox heterogeneity. Further, the development of quantitative global redox

579 tracers and better modeling are needed to place tighter constraints on the history of

580 oxygen on Earth. Nonetheless, the Fifteenmile Group redox structure is comparable to

581 that of a well-characterized Mesoproterozoic basin (Shen et al., 2003)—albeit with more

582 evidence for ferruginous conditions-- and both basins are consistent with broad estimates

583 for atmospheric oxygen levels between 1 and 40\% PAL (Kump, 2008).

584 Comparing these likely $\mathrm{O}_{2}$ levels with the estimated physiological requirements of

585 early animals suggests that sufficient atmospheric oxygen, even for mobile bilaterians,

586 was present well in advance of the origin of animals. Unless early Neoproterozoic oxygen

587 levels were substantially $<1 \%$ PAL, and likely $<0.4 \%$ PAL, atmospheric oxygen levels

588 would not have prohibited the sponge, eumetazoan and bilaterian body plans. This

589 conclusion does not imply that animals necessarily lived in the Fifteenmile basin, but

590 rather that global $\mathrm{O}_{2}$ levels were likely adequate for the presence of animals. Notably, this

591 does not negate the possibility of an oxygenation event around the Sturtian glaciation

592 (Planavsky et al., 2010; Frei et al., 2009), or the use of oxygenated 'oases' beneath

593 photosynthetic mats by the earliest trace makers in the geological record (Gingras et al., 
594 2011), but it does suggest that such conditions were not necessary for the origin of either

595 animals or bilaterians.

596 It is important to remember, though, that while low Precambrian oxygen levels

597 would not have prohibited animals, including bilaterians, the environmental milieu would

598 still have exerted a strong effect on life. Most importantly, low oxygen certainly would

599 have constrained these organisms to very small and thin body plans with little metabolic

600 scope (Raff and Raff, 1970; Runnegar, 1982a, b; Payne et al., 2010). Faunas in modern

601 low- $\mathrm{O}_{2} \mathrm{OMZ}$ analogues have very small body sizes, reduced diversity, and simple food

602 webs (Levin, 2003; Gooday et al., 2009; Sperling et al., in review). In other words,

603 although all available data suggests bilaterians can live down to 1\% PAL or less, the

604 fauna would be limited to a select few-those organisms that were a couple millimeters

605 in length and had low-energy lifestyles. Thus, while no oxygenation event need be

606 invoked to explain the origin of animals or bilaterians themselves, the hypothesized end-

607 Neoproterozoic oxygenation event (the timing and magnitude of which remains

608 debated—Kah and Bartley, 2011; Och and Shields-Zhou, 2012) may still have played a

609 role in the later Ediacaran diversification of macroscopic animals and the Cambrian

610 'Explosion' (e.g. Runnegar, 1982a; Rhoads and Morse, 1971; Knoll and Carroll, 1999).

611 Although Cambrian diversification was certainly multifaceted (Erwin et al., 2011), a

612 latest Proterozoic increase in oxygen levels could have allowed for an increase in both

613 size and metabolic scope, including potentially the advent of predation, a metabolically-

614 costly feeding strategy.

615

616 ACKNOWLEDGEMENTS 
617 We thank J. Strauss, A. Eyster, E. Smith and S. Braun for assistance in the field, A.

618 Masterson, E. Beirne, and B. Gill for technical assistance, G. Eischeid, G. Resendiz, D.

619 Cole and N. Waldo for help with sample preparation and laboratory analyses, P. Cohen,

620 P. Girguis, J. Payne, K. Peterson, J. Strauss, L. Levin and C. Frieder for helpful

621 discussion, and D. Fike and two anonymous reviewers for insightful comments. We

622 thank Fireweed Helicopters for safe and reliable transportation, and the Yukon

623 Geological Survey for field support. We thank D. Schrag, Harvard University Laboratory

624 for Chemical Oceanography, and S. Poulton, Newcastle University, for help with sample

625 analysis in their labs. EAS is supported by an Agouron Institute post-doctoral fellowship.

626 DTJ is supported by NSF EAR/IF, NASA Exobiology, and Harvard University. EAS,

627 AHK, DTJ and FAM thank the NASA Astrobiology Institute for support.

628

\section{FIGURE CAPTIONS}

630 Fig. 1- Location map of the Coal Creek and Tatonduk inliers, Yukon Territory, Canada, 631 with stars marking the location of the inliers.

632

633 Fig. 2- Geological map of the Coal Creek inlier, Ogilvie Mountains, Yukon Territory, 634 showing sections (in red) studied in this paper. The stratigraphic framework for basin 635 transects $\mathrm{A}-\mathrm{A}^{\prime}$ and $\mathrm{B}-\mathrm{B}^{\prime}$ are found in Fig. 3 and 4. The units studied as part of this 636 paper are the informal Gibben formation, Chandindu formation and Reefal Assemblage 637 of the Fifteenmile Group. Geological mapping by Macdonald et al. (2012). 
639 Fig. 3- Stratigraphic framework and iron speciation chemistry for transect A - A' at Mine

640 Camp, Mt. Harper and Mt. Gibben, Coal Creek inlier. Iron speciation chemistry

641 (specifically the ratio of highly reactive iron (FeHR) to total iron $(\mathrm{FeT})$ ) from fine-

642 grained siliciclastic rocks is plotted against the stratigraphic columns. Vertical line on

643 iron speciation plots denotes a ratio of 0.38 , with samples having higher ratios considered

644 to have been deposited under an anoxic water column, and samples with lower ratios

645 likely to have been deposited under an oxic water column. Complete redox proxy data for

646 individual sections is found in Fig. 6 (Mt. Harper), Supplemental Fig. 1 (Mine Camp),

647 Supplemental Fig. 2 (East Harper) and Supplemental Fig. 3 (Mt. Gibben). m- mud; si-

648 silt; $m s$ - medium sand; $c s$ - coarse sand; $c g$ - conglomerate. Gib. = Gibben formation.

650 Fig. 4- Stratigraphic framework and iron speciation chemistry for transect B - B' at

651 Reefer Camp, Coal Creek inlier. Sections are located $5 \mathrm{~km}$ apart and record a transition in

652 the Reefal Assemblage from a stromatolite reef complex into a deeper-water shale basin.

653 Iron speciation chemistry (specifically the ratio of highly reactive iron (FeHR) to total

654 iron $(\mathrm{FeT}))$ from fine-grained siliciclastic rocks is plotted against the stratigraphic

655 columns. Vertical line on iron speciation plots denotes a ratio of 0.38 , with samples

656 having higher ratios considered to have been deposited under an anoxic water column,

657 and samples with lower ratios likely to have been deposited under an oxic water column.

658 Complete redox proxy data for individual sections at Reefer Camp is found in Fig. 5.

659 Legend for stratigraphic columns and sediment type abbreviations as in Fig. 3.

660 Abbreviations: $W .=$ Wernecke Supergroup, Gib. $=$ Gibben formation, Cha.$=$ Chandindu 661 formation. 
663 Fig. 5- Redox proxy data from sections B' (Fig. 5A) and B (Fig. 5B) at Reefer Camp,

664 Coal Creek inlier. From left to right, proxy data plotted and their respective relevant

665 baseline data denoted by vertical red lines are: highly reactive to total iron $(\mathrm{FeHR} / \mathrm{FeT}$;

666 0.38), pyrite iron to highly reactive iron (FeP/FeHR; 0.80), total iron to total aluminum

667 (FeT/Al; 0.50), molybdenum (2.6 ppm), vanadium (130 ppm), pyrite sulfur isotope

668 values $(0 \%$ ), and weight percent total organic carbon. Relative base level curve from

669 sequence stratigraphic study of Macdonald et al. (2012). The far right column is a

670 subjective estimate of water column redox state based on the multi-proxy data, and is

671 meant to represent general trends rather than an estimate for every point. Euxinia(?)

672 denotes uncertainty regarding whether these samples represent deposition under a truly

673 euxinic water column or a ferruginous water column with sulfide production at or near

674 the sediment-water interface (see text). Legend for stratigraphic column and formation

675 name abbreviations as in Fig. 3 and 4.

677 Fig. 6- Redox proxy data from the Mt. Harper section, Coal Creek inlier. This figure is a 678 composite section from the Mt. Harper area (Fig. 2). Redox proxy data and their relevant 679 baseline values (marked by vertical red lines) as in Figure 5. Relative base level curve 680 from sequence stratigraphic study of Macdonald et al. (2012). The far right column is a 681 subjective estimate of water column redox state based on the multi-proxy data, and is 682 meant to represent general trends rather than an estimate for every point. Euxinia(?) 683 denotes uncertainty regarding whether these samples represent deposition under a truly 684 euxinic water column or a ferruginous water column with sulfide production at or near 
685 the sediment-water interface (see text). Legend for stratigraphic column and formation

686 name abbreviations as in Fig. 3 and 4.

688 Fig. 7- Redox proxy data from the Mt. Slipper section, Tatonduk inlier. Redox proxy data

689 and their relevant baseline values (marked by vertical red lines) as in Figure 5. Relative

690 base level curve from sequence stratigraphic study of Macdonald et al. (2012). The far

691 right column is a subjective estimate of water column redox state based on the multi-

692 proxy data, and is meant to represent general trends rather than an estimate for every

693 point. Euxinia(?) denotes uncertainty regarding whether these samples represent

694 deposition under a truly euxinic water column or a ferruginous water column with sulfide

695 production at or near the sediment-water interface (see text). Legend for stratigraphic

696 column and formation name abbreviations as in Fig. 3 and 4. Scale microfossils described

697 by Cohen et al. (2011) are found at the top of the Reefal Assemblage at this locality.

699 Fig. 8- Boxplot analysis of total organic carbon weight percentages for samples

700 determined likely to have been deposited under a ferruginous and euxinic water column.

701 Bottom-water redox state for each sample was estimated using a multi-proxy framework

702 including iron speciation data, redox-sensitive trace elements and pyrite sulfur isotope

703 values (see text for details). Samples designated as euxinic may represent sulfide

704 accumulation at the sediment-water interface rather than true water-column euxinia (see

705 text). The box represents the $25^{\text {th }}$ and $75^{\text {th }}$ percentiles, the thick horizontal line represents

706 the median, and the whiskers represent minimum and maximum values. An extreme 
707 outlier in the ferruginous set (E1002- 470.4; $9.87 \mathrm{wt} \%$ ) was included in the boxplot

708 calculations but not graphed.

709

710 Fig. 9- Theoretical minimum oxygen requirements for the last common ancestor (LCA)

711 of bilaterians, following the equations governing the diffusion of oxygen into an

712 organism from Alexander (1971) and modified by Payne et al. (2010). Estimates were

713 made for two potential body plans characterizing the bilaterian LCA, a $600 u \mathrm{~m}$ long

714 worm limited by pure diffusion, and a 3-mm long worm with a circulatory system. 'Most

715 likely' values represent values estimated from optimal values for all parameters (see

716 Supplemental Information). Minimum and maximum values were derived from the

717 literature for each parameter and global minimum and maximum values were estimated.

718 A sensitivity analysis was then conducted for each parameter by varying that parameter

719 between minimum and maximum values while keeping all other parameters at their 'most

720 likely' values. All estimates for oxygen requirements are far less than the $1 \%$ of Present

721 Atmospheric Levels indicated by canonical views of atmospheric oxygen levels in the

722 Proterozoic (Kump, 2008). Lowest row for extant mobile bilaterians shows the current

723 lower oxygen limit at which bilaterians are found in the modern ocean $\left(0.02 \mathrm{~mL} / \mathrm{L} \mathrm{O}_{2} \approx\right.$

$7240.33 \%$ of modern surface ocean levels assuming a normal surface ocean level of $6 \mathrm{~mL} / \mathrm{L}$ ).

725 Bilaterians are found at these levels off the coasts of Peru, Chile, and in the Bay of

726 Bengal. This oxygen level may represent an overestimate due to the methodology used to

727 measure oxygen in most benthic ecology studies (Breur et al., 2009 and see text).

729 References

730 
Alexander, R.M.N., 1971. Size and shape. Edward Arnold, London. p. 1-59.

Anderson, T.F., Raiswell, R., 2004. Sources and mechanisms for the enrichment of highly reactive iron in euxinic Black Sea sediments. American Journal of Science 304, 203-233.

Berney, C., Pawlowski, J., 2006. A molecular time-scale for eukaryote evolution recalibrated with the continuous microfossil record. Proceedings of the Royal Society London B 273, 1867-1872.

Brand, U., Veizer, J., 1980. Chemical diagenesis of a multicomponent carbonate system-1: trace elemens. Journal of Sedimentary Petrography 50, 1219-1236.

Breur, E.R., Law, G.T.W., Woulds, C., Cowie, G.L., Shimmield, G.B., Peppe, O., Schwartz, M., McKinlay, S., 2009. Sedimentary oxygen consumption and microdistribution at sites across the Arabian Sea oxygen minimum zone (Pakistan margin). Deep-Sea Research II 56, 296-304.

Budd, G.E., Jensen, S., 2000. A critical reappraisal of the fossil record of the bilaterian phyla. Biological Reviews 75, 253-295.

Butterfield, N.J., 2009. Oxygen, animals and oceanic ventilation: an alternative view. Geobiology 7, 1-7.

Butterfield, N.J., Knoll, A.H., Swett, K., 1994. Paleobiology of the Neoproterozoic Svanbergfjellet Formation, Spitsbergen. Lethaia 27, 76-76.

Campbell, I.H., Squire, R.J., 2010. The mountains the triggered the Late Neoproterozoic increase in oxygen: The second Great Oxidation Event. Geochimica et Cosmochimica Acta 74, 4187-3206.

Canfield, D.E., 2005. The early history of atmospheric oxygen: homage to Robert M. Garrels. Annu. Rev. Earth Planet. Sci. 33, 1-36.

Canfield, D.E., Poulton, S.W., Knoll, A.H., Narbonne, G.M., Ross, G., Goldberg, T., Strauss, H., 2008. Ferruginous conditions dominated later Neoproterozoic deepwater chemistry. Science 321, 949- 952.

Canfield, D.E., Raiswell, R., Westrich, J.T., Reaves, C.M., Berner, R.A., 1986. The use of chromium reduction in the analysis of reduced inorganic sulfur in sediments and shale. Chemical Geology 54, 149-155.

Carroll, S., Grenier, J., Weatherbee, S., 2001. From DNA to Diversity: Molecular Genetics and the Evolution of Animal Design (Malden, MA: Blackwell Science). Inc.

Catling, D.C., Glein, C.R., Zahnle, K.J., McKay, C.P., 2005. Why $\mathrm{O}_{2}$ Is Required by Complex Life on Habitable Planets and the Concept of Planetary "Oxygenation Time". Astrobiology 5, 415-438.

Celerin, M., Ray, J., Schisler, N., Day, A., Stetler-Stevenson, W., Laudenbach, D., 1996. Fungal fimbriae are composed of collagen. The EMBO journal 15, 4445-4453.

Chance, B., 1957. Cellular oxygen requirements. Federation Proceedings 16, 671-680.

Cloud Jr, P.E., 1968. Atmospheric and hydrospheric evolution on the primitive Earth. Science 160, 729-736.

Cohen, P.A., Schopf, J.W., Butterfield, N.J., Kudryavtsev, A.B., Macdonald, F.A., 2011. Phosphate biomineralization in mid-Neoproterozoic protists. Geology 39, 539542.

Cohen, P.A., Knoll, A.H., 2012. Neoproterozoic scale microfossils from the Fifteenmile Group, Yukon Territory. Journal of Paleontology 86, 775-800. 
Danovaro, R., Dell'Anno, A., Pusceddu, A., Gambi, C., Heiner, I., Kristensen, R.M., 2010. The first metazoa living in permanently anoxic conditions. BMC Biology 8 , 30.

Diaz, R.J., Rosenberg, R., 1995. Marine benthic hypoxia: a review of its ecological effects and the behavioural responses of benthic macrofauna. Oceanography and Marine Biology Annual Review 33, 245-303.

Erwin, D.H., Davidson, E.H., 2002. The last common bilaterian ancestor. Development 129, 3021-3032.

Erwin, D.H., Laflamme, M., Tweedt, S.M., Sperling, E.A., Pisani, D., Peterson, K.J., 2011. The Cambrian conundrum: Early divergence and later ecological success in the early history of animals. Science 334, 1091-1097.

Farquhar, J., Bao, H., Thiemens, M., 2000. Atmospheric influence of earth's earliest sulfur cycle. Science $289,756-758$.

Farrell, U.C., 2011. Taphonomy and Paleoecology of Pyritized Trilobite Faunas from Upstate New York. Yale University, New Haven, CT, p. 1-430.

Frei, R., Gaucher, C., Poulton, S.W., Canfield, D.E., 2009. Fluctuations in Precambrian atmospheric oxygenation recorded by chomium isotopes. Nature 461, 250-253.

Fujimoto, D., Tamiya, N., 1962. Incorporation of ${ }^{18} \mathrm{O}$ from air into hydroxyproline by chick embryo. Biochemical Journal 84, 333-335.

Gingras, M., Hagadorn, J.W., Seilacher, A., Lalonde, S.V., Pecoits, E., Petrash, D., Konhauser, K.O., 2011. Possible evolution of mobile animals in association with microbial mats. Nature Geoscience 4, 372-375.

Gnaiger, E., Mendez, G., Hand, S.C., 2000. High phosphorylation efficiency and depression of uncoupled respiration in mitochondria under hypoxia. Proceedings of the National Academy of Sciences 97, 11080-11085.

Gooday, A.J., Bett, B.J., Escobar, E., Ingole, B., Levin, L.A., Neira, C., Raman, A.V., Sellanes, J., 2010. Habitat heterogeneity and its influence on benthic biodiversity in oxygen minimum zones. Marine Ecology 31, 125-147.

Gooday, A.J., Levin, L.A. da Silva, A.A., Bett, B.J., Cowie, G.L., Dissard, D., Gage, J.D., Hughes, D.J., Jeffreys, R., Lamont, P.A., Larkin, K.E., Murty, S.J., Schumacher, S., Whitcraft, C., Woulds, C., 2009. Faunal responses to oxygen gradients on the Pakistan margin: A comparison of foraminiferans, macrofauna and megafauna. Deep-Sea Research II 56, 488-502.

Gromet, L.P., Dymek, R.F., Haskin, L.A., Korotev, R.L., 1984. The "North American shale composite": Its compilation, major and trace element characteristics. Geochimica et Cosmochimica Acta 48, 2469-2482.

Hofmann, A., Peltzer, E., Walz, P., Brewer, P., 2011. Hypoxia by degrees: Establishing definitions for a changing ocean. Deep Sea Research Part I: Oceanographic Research Papers 58, 1212-1226.

Holland, H.D., Beukes, N.J., 1990. A paleoweathering profile from Griqualand West, South Africa: evidence for a dramatic rise in atmospheric oxygen between 2.2 and 1.9 bybp. American Journal of Science 290A, 1-34.

Ingole, B.S., Sautya, S., Sivadas, S., Singh, R., Nanajkar, M., 2010. Macrofaunal community structure in the western Indian continental margin including the oxygen minimum zone. Marine Ecology 31, 148-166. 
Jeffreys, R.M., Levin, L.A., Lamont, P.A., Woulds, C., Whitcraft, C.R., Mendoza, G.F., Wolff, G.A., Cowie, G.L., 2012. Living on the edge: single-species dominance at the Pakistan oxygen minimum zone boundary. Marine Ecology Progress Series 470, 79-99.

Johnston, D.T., Poulton, S.W., Dehler, C.M., Porter, S., Husson, J., Canfield, D.E., Knoll, A.H., 2010. An emerging picture of Neoproterozoic ocean chemistry: Insights from the Chuar Group, Grand Canyon, USA. Earth and Planetary Science Letters 290, 64-73.

Johnston, D.T., Fischer, W.W., 2012. Stable isotope geobiology, in: Knoll, A.H., Canfield, D.E., Konhauser, K.O. (Eds.), Fundamentals of Geobiology. Blackwells, Chichester, pp. 250-266.

Kah, L.C., Bartley, J.K., 2011. Protracted oxygenation of the Proterozoic biosphere. International Geology Review 53, 1424-1442.

Karlstrom, K.E., Bowring, S.A., Dehler, C.M., Knoll, A.H., Porter, S.M., Des Marais, D.J., Weil, A.B., Sharp, Z.D., Geissman, J.W., Elrick, M.B., 2000. Chuar Group of the Grand Canyon: Record of breakup of Rodinia, associated change in the global carbon cycle, and ecosystem expansion by 740 Ma. Geology 28, 619-622.

King, N., Westbrook, M.J., Young, S.L., Kuo, A., Abedin, M., Chapman, J., Fairclough, S., Hellsten, U., Isogai, Y., Letunic, I., Marr, M., Pincus, D., Putnam, N., Rokas, A., Wright, K.J., Zuzow, R., Dirks, W., Good, M., Goodstein, D., Lemons, D., Li, W., Lyons, J.B., Morris, A., Nichols, S., Richter, D.J., Salamov, A., Sequencing, J., Bork, P., Lim, W.A., Manning, G., Miller, W.T., McGinnis, W., Shapiro, H., Tijan, R., Grigoriev, I.V., Rokhsar, D., 2008. The genome of the choanoflagellate Monosiga brevicollis and the origin of metazoans. Nature 451, 783-788.

Knoll, A.H., 2011. The multiple origins of complex multicellularity. Annual Review of Earth and Planetary Sciences 39, 217-239.

Knoll, A.H., Bambach, R.K., Payne, J.L., Pruss, S., Fischer, W., 2007. Paleophysiology and end-Permian mass extinction. Earth and Planetary Science Letters 256, 295313.

Knoll, A.H., Carroll, S.B., 1999. Early animal evolution: Emerging views from comparative biology and geology. Science 284, 2129-2137.

Knoll, A.H., Javaux, E.J., Hewitt, D., Cohen, P., 2006. Eukaryotic organisms in Proterozoic oceans. Philosophical Transactions of the Royal Society London Series B 361, 1023-1038.

Kodner, R.B., Summons, R.E., Pearson, A., King, N., and Knoll, A.H., 2008. Sterols in a unicellular relative of the metazoans. Proceedings of the National Academy of Sciences, USA 105, 9897-9902.

Kump, L.R., 2008. The rise of atmospheric oxygen. Nature 451, 277-278.

Kump, L.R., Pavlov, A., Arthur, M.A., 2005. Massive release of hydrogen sulfide to the surface ocean and atmosphere during intervals of oceanic anoxia. Geology 33, 397-400.

Lamont, P.A., Gage, J.D., 2000. Morphological responses of macrobenthic polychaetes to low oxygen on the Oman continental slope, NW Arabian Sea. Deep-Sea Research II $47,9-24$. 
Lartillot, N., Lepage, T., Blanquart, S., 2009. PhyloBayes 3: a Bayesian software package for phylogenetic reconstruction and molecular dating. Bioinformatics 25, 22862288.

Levin, L., Ekau, W., Gooday, A., Jorissen, F., Middelburg, J., Naqvi, W., Neira, C., Rabalais, N., Zhang, J., 2009. Effects of natural and human-induced hypoxia on coastal benthos. Biogeosciences Discussions 6, 3563-3654.

Levin, L., Gutierrez, D., Rathburn, A., Neira, C., Sellanes, J., Munoz, P., Gallardo, V., Salamanca, M., 2002. Benthic processes on the Peru margin: a transect across the oxygen minimum zone during the 1997-98 El Niño. Progress in Oceanography 53, 1-27.

Levin, L.A., 2003. Oxygen Minimum Zone benthos: adaptation and community response to hypoxia. Oceanography and Marine Biology: an Annual Review 41, 1-45.

Levin, L.A., Huggett, C.L., Wishner, K.F., 1991. Control of deep-sea benthic community structure by oxygen and organic-matter gradients in the eastern Pacific Ocean. Journal of Marine Research 49, 763-800.

Love, G.D., Grosjean, E., Stalvies, C., Fike, D.A., Grotzinger, J.P., Bradley, A.S., Kelly, A.E., Bhatia, M., Meredith, W., Snape, C.E., Bowring, S.A., Condon, D.J., Summons, R.E., 2009. Fossil steroids record the appearance of Demospongiae during the Cryogenian period. Nature 457, 718-721.

Lyons, T.W., Severmann, S., 2006. A critical look at iron paleoredox proxies: New insights from modern euxinic marine basins. Geochimica et Cosmochimica Acta $70,5698-5722$.

Macdonald, F.A., Halverson, G.P., Strauss, J.V., Smith, E.F., Cox, G., Sperling, E.A., Roots, C.F., 2012. Early Neoproterozoic basin formation in the Yukon: implications for the make-up and break-up of Rodinia. Geoscience Canada 39, 77-99.

Macdonald, F.A., Schmitz, M.D., Crowley, J.L., Roots, C.F., Jones, D.S., Maloof, A.C., Strauss, J.V., Cohen, P.A., Johnston, D.T., Schrag, D.P., 2010. Calibrating the Cryogenian. Science 327, 1241-1243.

Nagy, R.M., Porter, S.M., Dehler, C.M., Shen, Y., 2009. Biotic turnover driven by eutrophication before the Sturtian low-latitude glaciation. Nature Geoscience 2, 415-418.

Narbonne, G.M., 2011. When life got big. Nature 470, 339-340.

Neira, C., Gad, G., Arroyo, N.L., Decraemer, W., 2001. Glochinema bathyperuvensis sp. n. (Nematoda, Epsilonematidae): a new species from Peruvian bathyal sediments, SE Pacific Ocean. Contributions to Zoology 70, 147-159.

Nesbitt, H., Young, G., 1982. Early Proterozoic climates and plate motions inferred from major element chemistry of lutites. Nature 299, 715-717.

Och, L.M., Shields-Zhou, G.A., 2012. The Neoproterozoic oxygenation event: environmental perturbations and biogeochemical cycling. Earth Science Reviews 110, 26-57.

Palma, M., Quiroga, E., Gallardo, V.A., Arntz, W., Gerdes, D., Schneider, W., Hebbeln, D., 2005. Macrobenthic animal assemblages of the continental margin off Chile $\left(22^{\circ}\right.$ to $\left.42^{\circ} \mathrm{S}\right)$. Journal of the Marine Biological Association of the UK 85, 233245. 
Parfrey, L.W., Lahr, D.J.G., Knoll, A.H., Katz, L.A., 2011. Estimating the timing of early eukaryotic diversification with multigene molecular clocks. Proceedings of the National Academy of Sciences, U.S.A. 108, 13624-13629.

Paulmier, A., Ruiz-Pino, D., Garçon, V., Farias, L., 2006. Maintaining of the eastern south Pacific oxygen minimum zone (OMZ) off Chile. Geophysical Research Letters 33, L20601.

Pavlov, A., Kasting, J., 2002. Mass-independent fractionation of sulfur isotopes in Archean sediments: strong evidence for an anoxic Archean atmosphere. Astrobiology 2, 27-41.

Payne, J.L., McClain, C.R., Boyer, A.G., Brown, J.H., Finnegan, S., Kowalewski, M., Krause, J.R.A., Lyons, S.K., McShea, D.W., Novack-Gottshall, P.M., Smith, F.A., Spaeth, P., Stempien, J.A., Wang, S.C., 2010. The evolutionary consequences of oxygenic photosynthesis: a body size perspective. Photosynthesis Research 107, 37-57.

Peters, S.E., Loss, D.P., 2012. Storm and fair-weather wave base: A relevant distinction? Geology 40, 511-514.

Philippe, H., Brinkmann, H., Lavrov, D.V., Littlewood, D.T.J., Manuel, M., Worheide, G., Baurain, D., 2011. Resolving difficult phylogenetic questions: why more sequences are not enough. PLoS Biology 9, e1000602.

Philippe, H., Derelle, R., Lopez, P., Pick, K., Borchiellini, C., Boury-Esnault, N., Vacelet, J., Deniel, E., Houliston, E., Queinnec, E., Da Silva, C., Wincker, P., Le Guyader, H., Leys, S., Jackson, D.J., Scheiber, F., Erpenbeck, D., Morgenstern, B., Worheide, G., Manuel, M., 2009. Phylogenomics restores traditional views on deep animal relationships. Current Biology 19, 706-712.

Planavsky, N.J., Rouxel, O.J., Bekker, A., Lalonde, S.V., Konhauser, K.O., Reinhard, C.T., Lyons, T.W., 2010. The evolution of the marine phosphate reservoir. Nature 467, 1088-1090.

Porter, S.M., Knoll, A.H., 2000. Testate amoeba in the Neoproterozoic Era: evidence from vase-shaped microfossils in the Chuar Group, Grand Canyon. Paleobiology 26, 360-385.

Porter, S.M., Meisterfeld, R., Knoll, A.H., 2003. Vase-shaped microfossils from the Neoproterozoic Chuar Group, Grand Canyon: a classification guided by modern testate amoebae. Journal of Paleontology 77: 205-225.

Poulton, S., Raiswell, R., 2002. The low-temperature geochemical cycle of iron: from continental fluxes to marine sediment deposition. American Journal of Science 302, 774-805.

Poulton, S.W., Canfield, D.E., 2005. Development of a sequential extraction procedure for iron: implications for iron partitioning in continentally derived particulates. Chemical Geology 214, 209-221.

Poulton, S.W., Canfield, D.E., 2011. Ferruginous conditions: A dominant feature of the ocean through Earth's history. Elements 7, 107-112.

Prockop, D., Kaplan, A., Udenfriend, S., 1963. Oxygen-18 studies on the conversion of proline to collagen hydroxyproline. Archives of Biochemistry and Biophysics 101, 499-503.

Raff, R.A., Raff, E.C., 1970. Respiratory mechanisms and the metazoan fossil record. Nature 228, 1003-1005. 
Rainbird, R.H., Jefferson, C.W., Young, G.M., 1996. The early Neoproterozoic sedimentary Succession B of northwestern Laurentia: Correlations and paleogeographic significance. Geological Society of America Bulletin 108, 454470.

Raiswell, R., Canfield, D.E., 1998. Sources of iron for pyrite formation in marine sediments. American Journal of Science 298, 219-245.

Rhoads, D.C., Morse, J.W., 1971. Evolutionary and ecologic significance of oxygendeficient marine basins. Lethaia 4, 413-428.

Runnegar, B., 1982a. The Cambrian explosion: animals or fossils? Journal of the Geological Association of Australia 29, 395-411.

Runnegar, B., 1982b. Oxygen requirements, biology and phylogenetic significance of the late Precambrian worm Dickinsonia, and the evolution of the burrowing habit. Alcheringa 6, 223-239.

Runnegar, B., 1991. Precambrian oxygen levels estimated from the biochemistry and physiology of early eukaryotes. Palaeogeography, Palaeoclimatology, Palaeoecology 97, 97-111.

Ruppert, E.E., Fox, R.S., Barnes, R.D., 2004. Invertebrate Zoology. Thomson, Belmont, CA. p. 1-963.

Sahoo, S.K., Planavsky, N.J., Kendall, B., Wang, X., Shi, X., Scott, C., Anbar, A.D., Lyons, T.W., Jiang, G., 2012. Ocean oxygenation in the wake of the Marinoan glaciation. Nature 489, 546- 549.

Scott, C., Lyons, T.W., Bekker, A., Shen, Y., Poulton, S.W., Chu, X., Anbar, A.D., 2008. Tracing the stepwise oxygenation of the Proterozoic ocean. Nature 452, 456-459.

Shen, Y., Knoll, A.H., Walter, M.R., 2003. Evidence for low sulphate and anoxia in a mid-Proterozoic marine basin. Nature 423, 632-635.

Sperling, E.A., Peterson, K.J., Pisani, D., 2009. Phylogenetic-signal dissection of nuclear housekeeping genes supports the paraphyly of sponges and the monophyly of Eumetazoa. Molecular Biology and Evolution 26, 2261-2274.

Sperling, E.A., Robinson, J.M., Pisani, D., Peterson, K.J., 2010. Where's the glass? Biomarkers, molecular clocks, and microRNAs suggest a 200-Myr missing Precambrian fossil record of siliceous sponges. Geobiology 8, 24-36.

Sperling, E.A., Frieder, C.A., Raman, A., Girguis, P.R., Levin, L.A., Knoll, A.H., in review. Oxygen, ecology, and the Cambrian radiation of animals. Nature Geoscience.

Terwilliger, N.B., 1998. Functional adaptations of oxygen-transport proteins. Journal of experimental biology 201, 1085-1098.

Thorkelson, D.J., Abbott, J.G., Mortensen, J.K., Creaser, R.A., Velleneuve, M.E., McNicoll, V.J., Layer, P.W., 2005. Early and Middle Proterozoic evolution of Yukon, Canada. Canadian Journal of Earth Sciences 42, 1045-1071.

Tribovillard, N., Algeo, T.J., Lyons, T., Riboulleau, A., 2006. Trace metals as paleoredox and paleoproductivity proxies: An update. Chemical Geology 232, 12-32.

Towe, K.M., 1970. Oxygen-collagen priority and the early metazoan fossil record. Proceedings of the National Academy of Sciences, U.S.A. 65, 781-788.

Tyson, R.V., Pearson, T.H., 1991. Modern and ancient continental shelf anoxia: an overview, in: Tyson, R.V., Pearson, T.H. (Eds.), Modern and Ancient Continental Shelf Anoxia. Geological Society Special Publications, London, pp. 1-24. 
1003 Vaquer-Sunyer, R., Duarte, C.M., 2008. Thresholds of hypoxia for marine biodiversity. 1004 Proceedings of the National Academy of Sciences 105, 15452-15457.

1005 Wang, C., Leger, R.J.S., 2006. A collagenous protective coat enables Metarhizium 1006 anisopliae to evade insect immune responses. Proceedings of the National 1007 Academy of Sciences 103, 6647-6652.

1008 Zettler, M.L., Bochert, R., Pollehne, F., 2009. Macrozoobenthos diversity in an oxygen 1009 minimum zone off northern Namibia. Marine Biology 156, 1949-1961. 


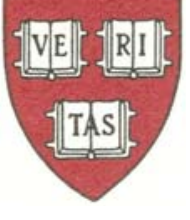

\author{
HARVARD UNIVERSITY \\ DEPARTMENT OF EARTH AND Planetary SCIENCES \\ 20 OXFORD ST. \\ CAMBRIDGE, MA 02138 \\ TEL. (617) 495-2351 FAX. (617) 495-8839
}

Highlights for Sperling et al.

1) We present the first early Neoproterozoic basin redox transect

2) Redox proxy data are consistent with quantitative constraints on Proterozoic $\mathrm{O}_{2}$

3) Inferred Proterozoic oxygen levels would not prohibit the presence of animals 
Click here to download Figure: Figure 1 Locality map.pdf

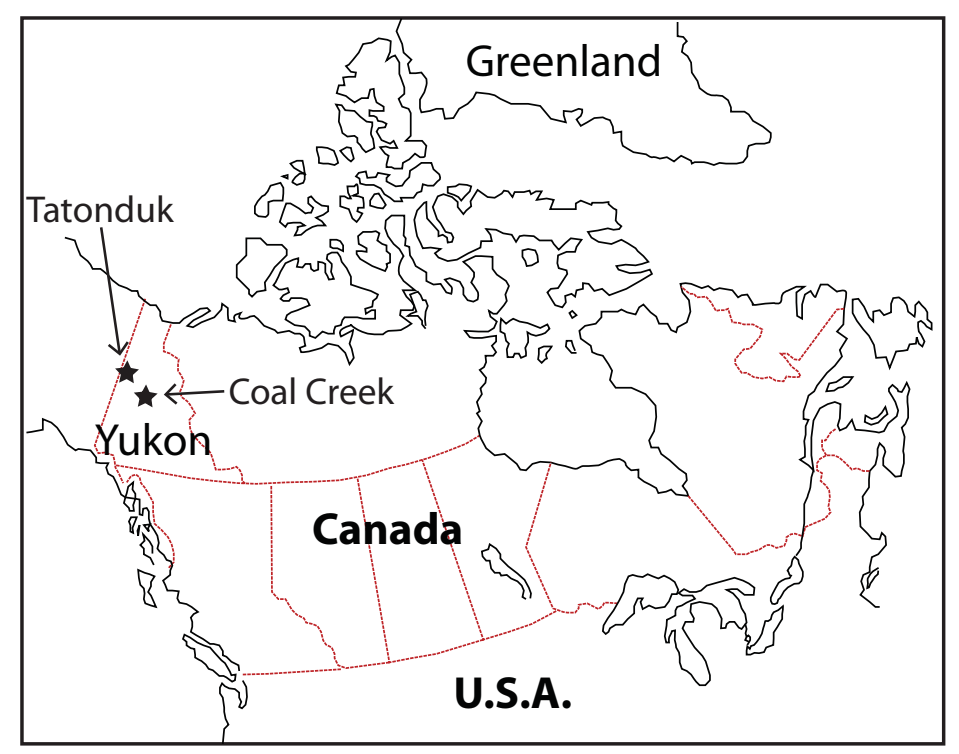




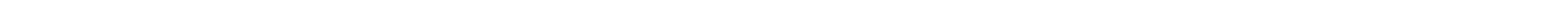


Figure 3

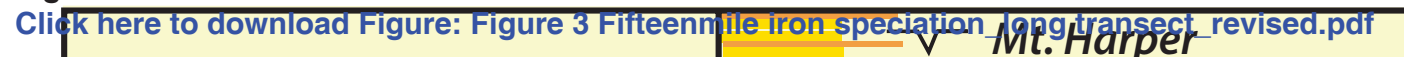

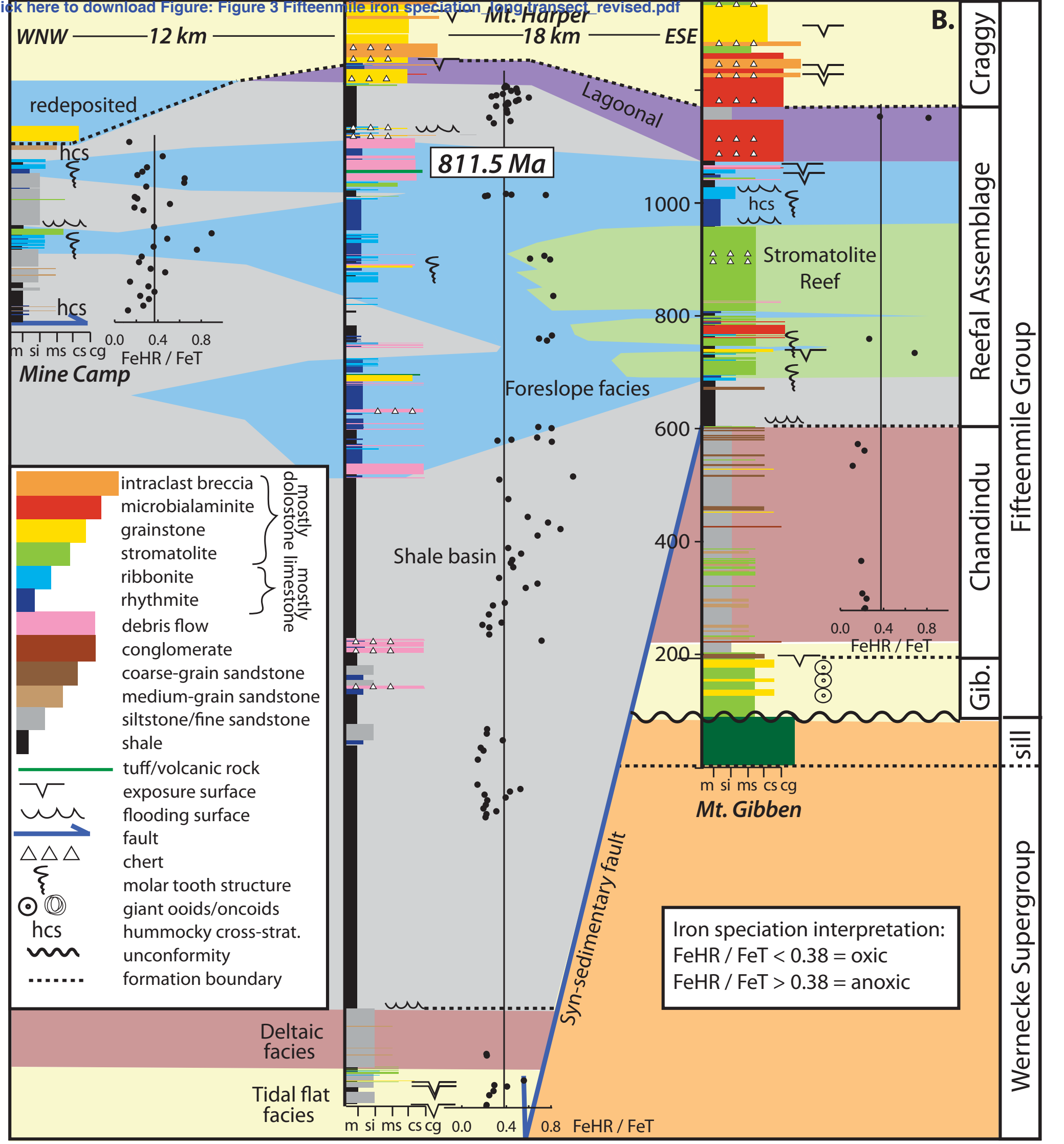




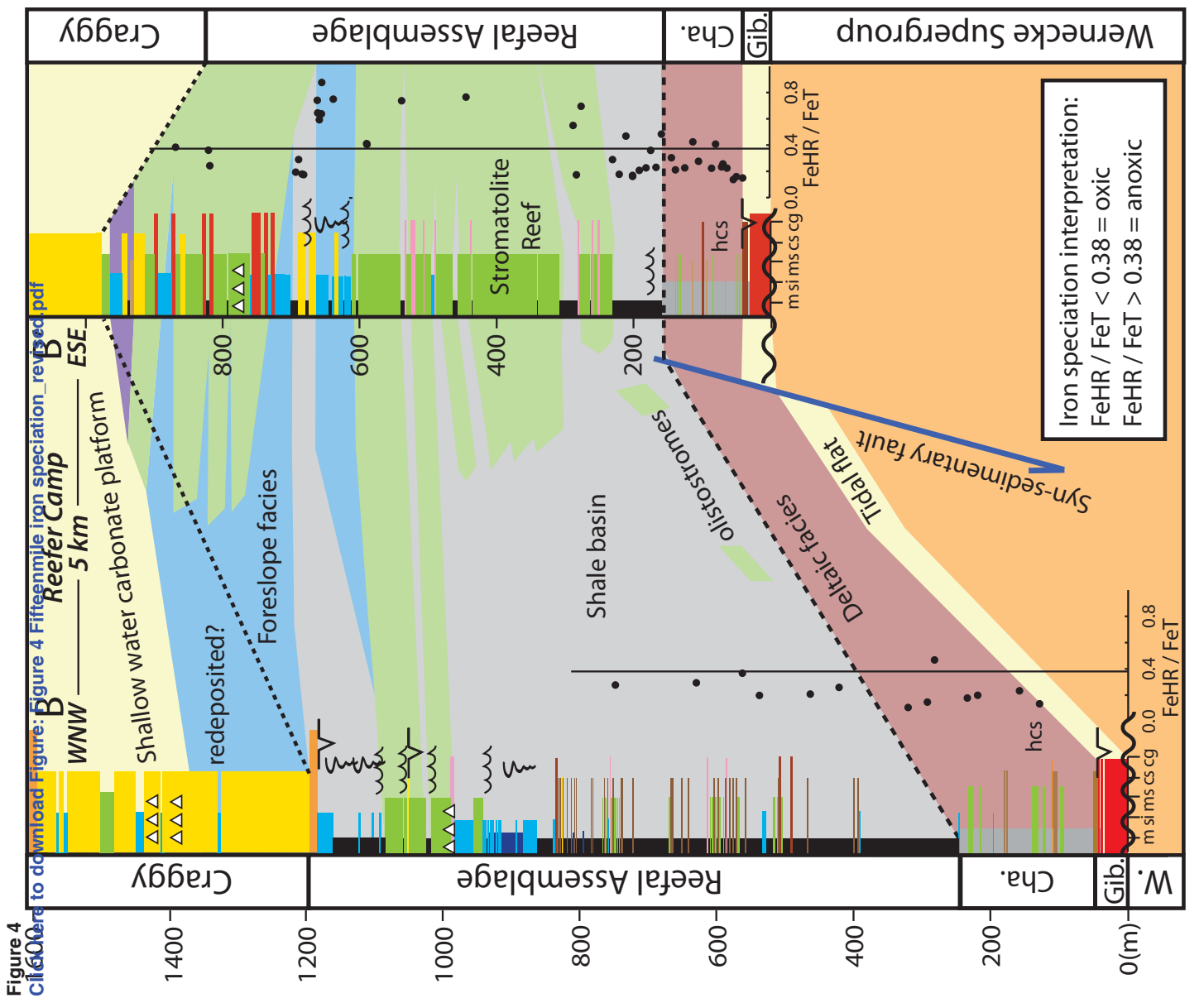



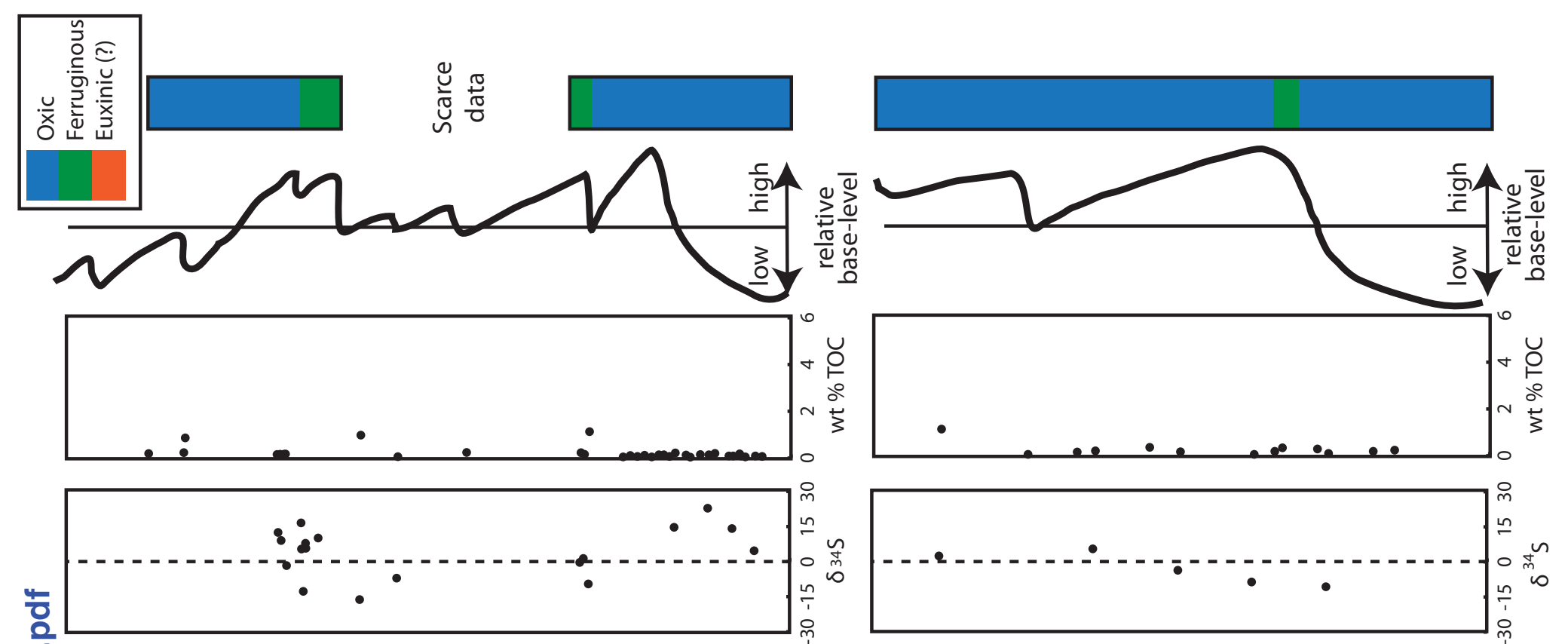

요

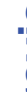

$$
\text { 푹 }
$$

ㄴ.$$
\text { (0) }
$$$$
\text { . }
$$$$
\text { 논 }
$$$$
\text { i }
$$
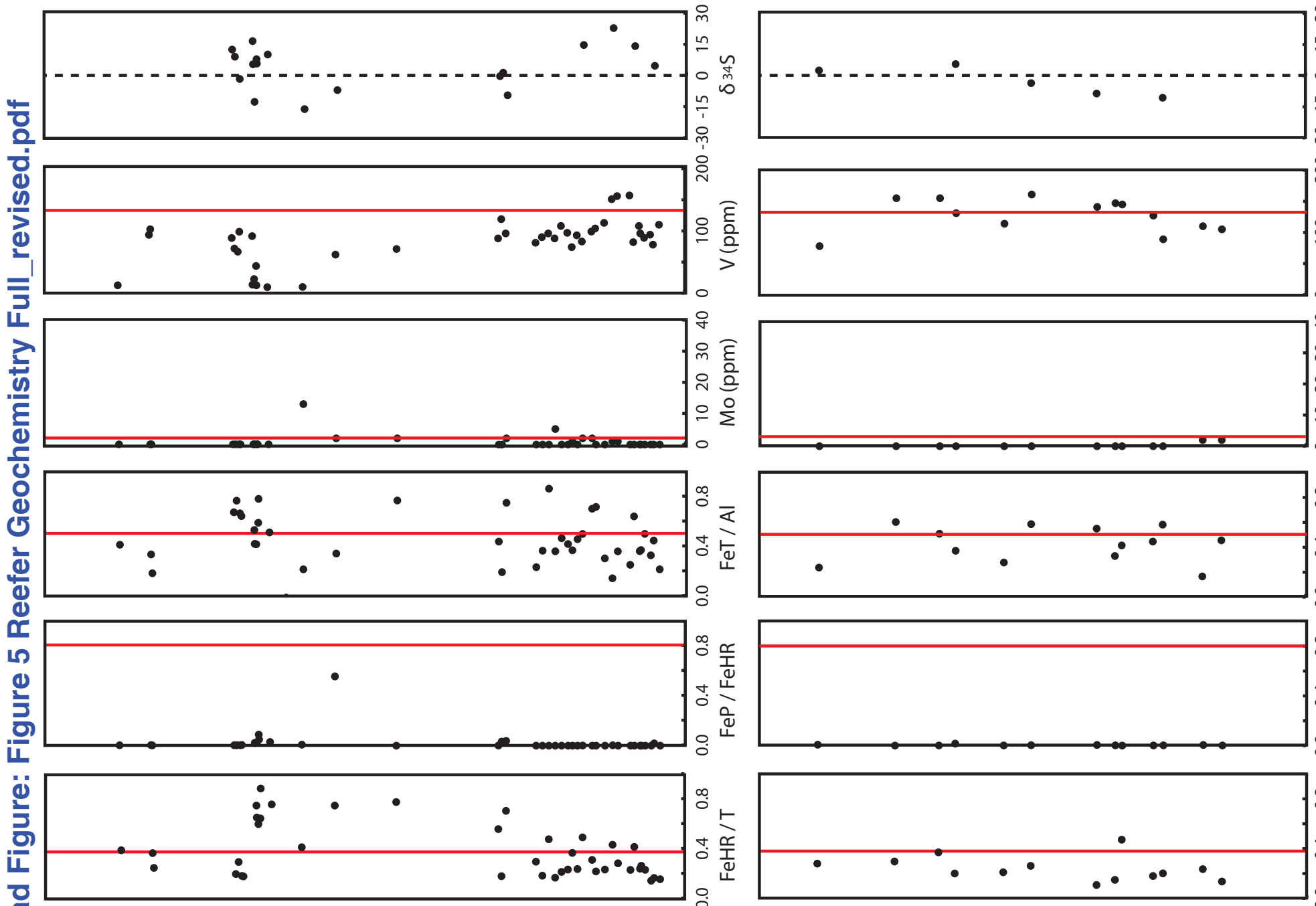

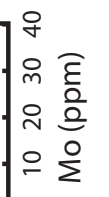
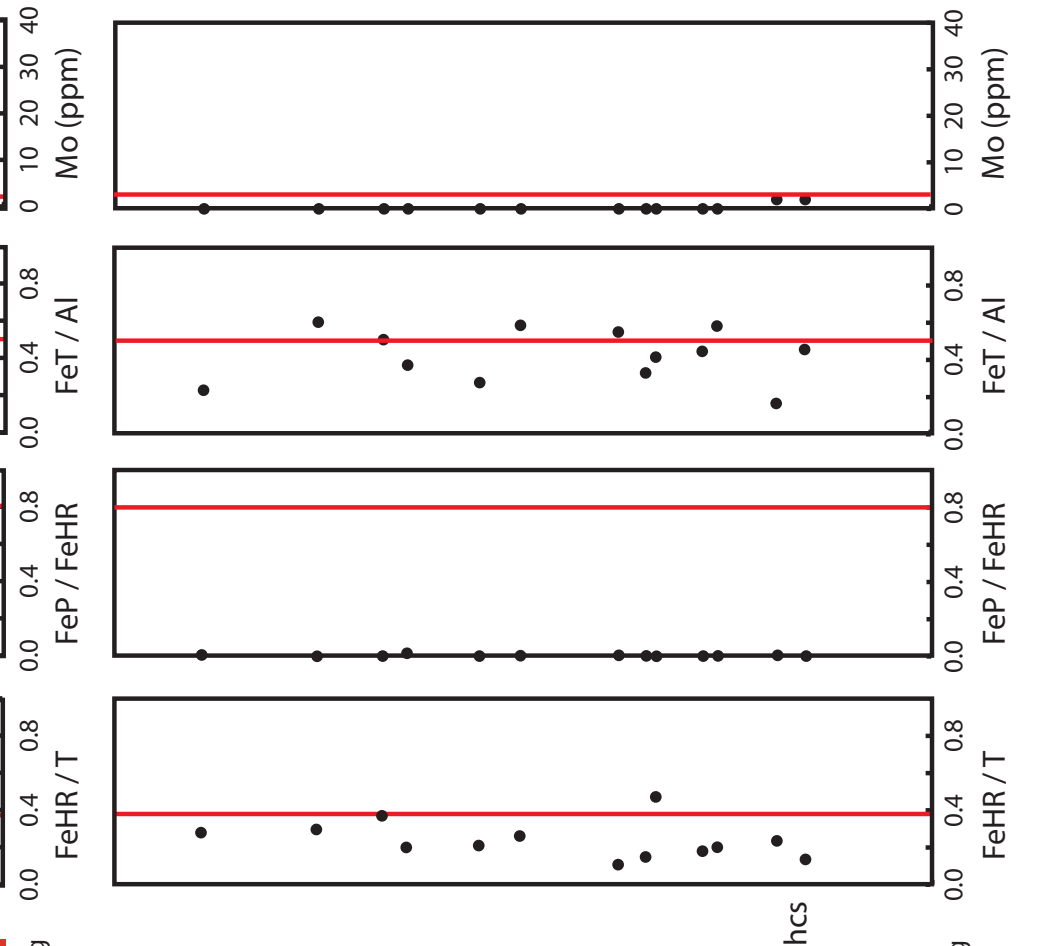

응

웅

in

dํ.

는

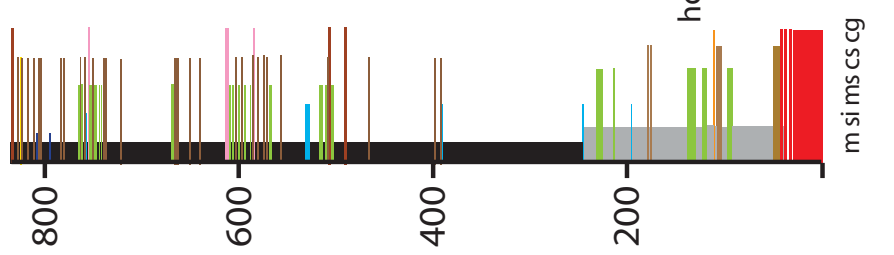

1205

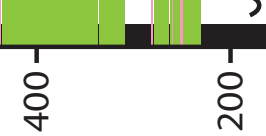

$8+01-1$

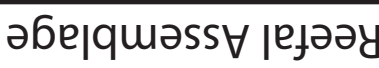

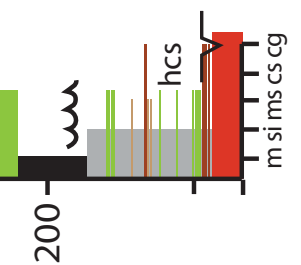



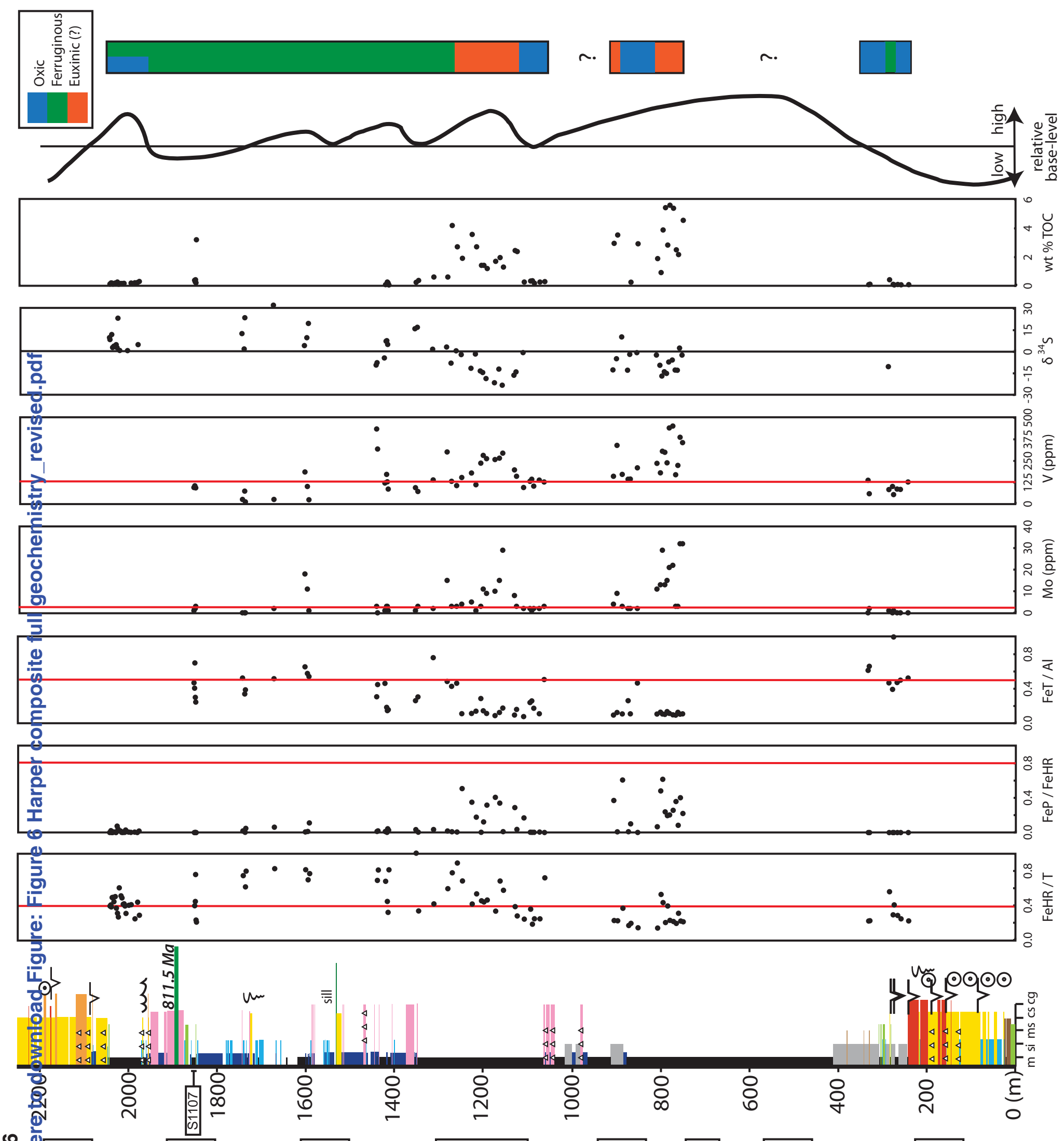

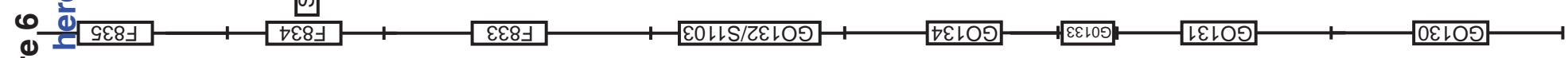

\begin{tabular}{|c|c|c|c|}
\hline 柏6еג & әбе|quәss $\forall$ ןејәәу & •ечว & uəqq!९ \\
\hline
\end{tabular}




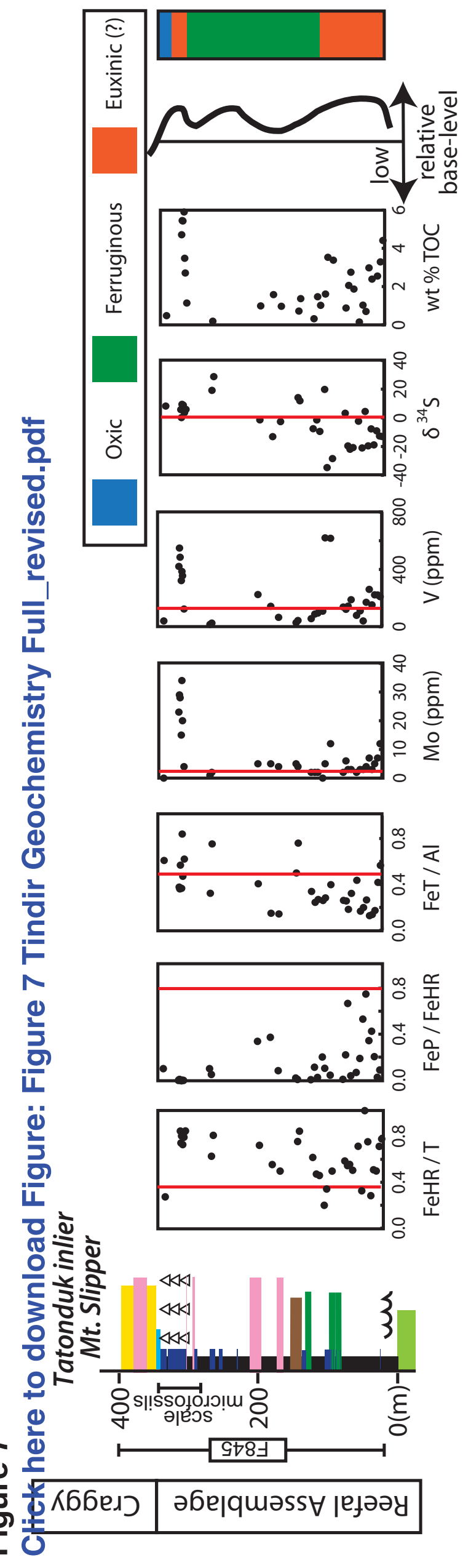




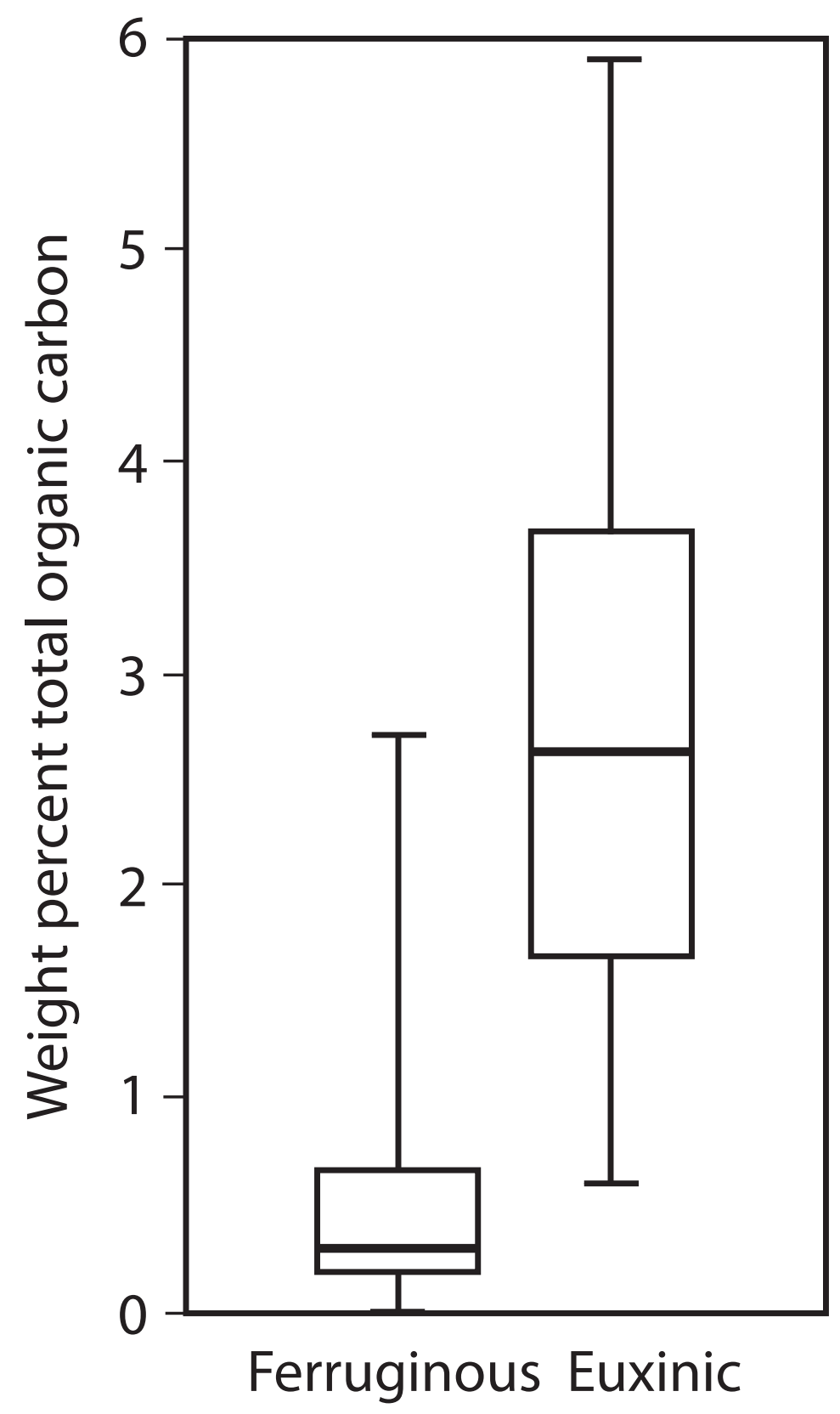




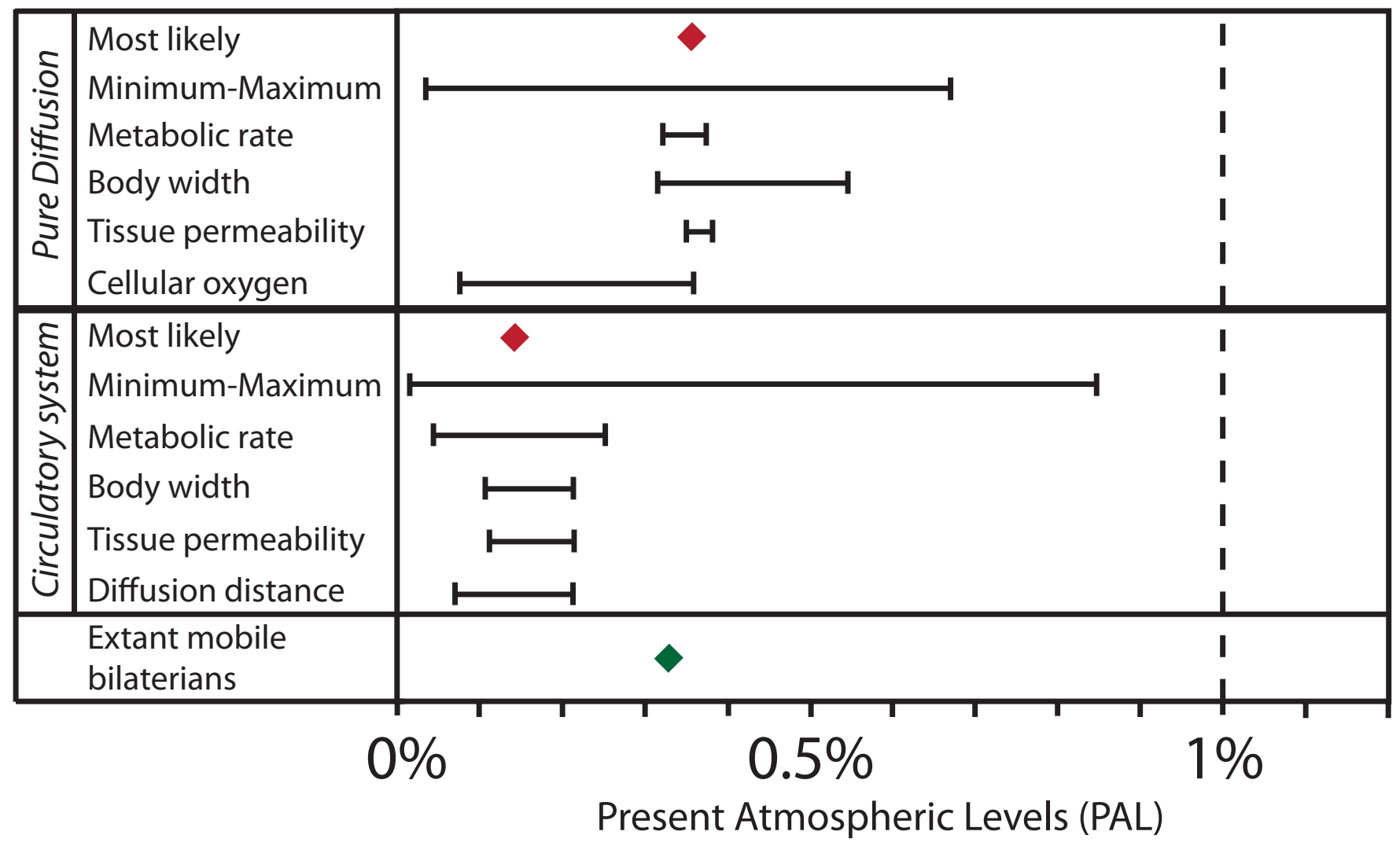

